\title{
Socio-economic gaps in subject interest: the mediating role of parental cognitive involvement
}

\author{
Daniel H. Caro
}

*Correspondence:
dcarov@gmail.com
University of Oxford, Oxford,
UK

${ }^{*}$ Correspondence:

University of Oxford, Oxford, UK

\begin{abstract}
This paper examines the mediating role of parental literacy and numeracy involvement before the child entered school in the relationship between family socio-economic status (SES) and students' interest in reading and mathematics. Causal mediation analysis is applied to international assessment data from the Trends in International Mathematics and Science Study-Progress in International Reading Literacy Study 2011 combined study. Results provide weak support for the subject-specific parental cognitive involvement mediating mechanism in the association between family SES and subject-specific interest. In general, the total association with family SES is not strong and the direct role of parental cognitive involvement in students' interest appears to be more relevant than its role via family SES.
\end{abstract}

Keywords: SES, Subject interest, Literacy involvement, TIMSS, PIRLS

\section{Background}

Equity in education can be conceptualised from different perspectives with different normative and measurement implications (Strietholt and Borgna 2016). From an egalitarian perspective, all inequalities in educational outcomes are regarded as unfair and equity is thus measured through simple dispersion indicators (e.g., standard deviation of academic achievement). From a capability approach, a minimum level of educational attainment is expected and inequalities can therefore be measure through, for example, the percentage of students reaching a basic literacy level (e.g., students performing above proficiency level 2 in the Programme for International Student Assessment [PISA] test). From an equality of opportunity perspective inequalities that are beyond individual control are unfair and equity is measured through the association between educational outcomes and family background characteristics (e.g., family socio-economic status [SES]) or student characteristics (e.g., gender).

International assessment studies like the Progress in International Reading Literacy Study (PIRLS), the Trends in International Mathematics and Science Study (TIMSS), and PISA have contributed valuable data for characterising and comparing different measures of equity in education within and between education systems. Particularly, a great deal of effort has gone into investigating equality of opportunity in relation to family SES.

(c) The Author(s) 2018. This article is distributed under the terms of the Creative Commons Attribution 4.0 International License (http://creativecommons.org/licenses/by/4.0/), which permits unrestricted use, distribution, and reproduction in any medium, provided you give appropriate credit to the original author(s) and the source, provide a link to the Creative Commons license, and indicate if changes were made. 
Willms (2006) has developed an analytical framework for the study of education inequalities with large-scale assessment data. The framework consists of producing a single measure of family socio-economic status (SES) with data on parental education, parental occupations, and family wealth, and examining different aspects of the relationship between family SES and student outcomes. Socio-economic gradients estimated with multilevel modeling techniques summarize the relationship between family SES and student outcomes. They characterise education inequalities within schools, between schools, and between education systems. The socio-economic gradient framework has been adopted by PISA since 2000 (e.g., OECD 2013a). It has also been applied to measure SES and study education inequalities with PIRLS data (Caro and Cortés 2012; Caro and Lenkeit 2012). A number of questions relevant to equity and policy research in education have been addressed using this framework and in related work with international assessment data.

For instance, researches have studied the family cultural mechanisms underlying SES achievement inequalities (Pokropek et al. 2015; Tramonte and Willms 2010), the mediating role of home learning environment in SES achievement gaps (Caro 2015; Park 2008a), changes in the associations between family SES and student achievement (Yang Hansen et al. 2011), regional differences in education inequality (e.g., Caro and Mirazchiyski 2012), whether the association between academic achievement and parent-child communication varies across levels of family SES (Caro 2011; Park 2008b), whether teacher characteristics interact with the student SES (Caro et al. 2016; Luschei and Chudgar 2011), whether family SES accounts for the achievement gap between students with and without migration background (Shapira 2012), and whether the school SES composition has a role in student achievement in addition to the student SES (Caro and Lenkeit 2012; Willms 2003, 2006).

While international assessment studies present limitations for examining education inequalities, for example, in terms of cross-cultural comparability, theoretical implications, and causal interpretation of results (e.g., Caro et al. 2014), these studies have provided valuable empirical evidence on the degree of inequalities, levels of inequalities (e.g., students /schools/education systems), mediating and moderating factors for inequalities, among other aspects that contribute to characterising education inequalities and understanding how inequalities arise and can be reduced.

For the most part, studies have looked at SES gaps in student achievement outcomes and family SES inequalities in metacognitive skills have been less frequently investigated with international assessment data. Equity studies have been criticised for reducing its scope to academic outcomes and current educational theories advocate the study of broader outcomes than student achievement (Creemers and Kyriakides 2008). With this in mind, the present study examines family SES gaps in students' subject-specific interest. Particularly, it examines the mediating role of parental cognitive involvement in the relationship between family SES and students' interest in reading and mathematics.

Mediation is analysed from a causal perspective (Caro 2015; Imai et al. 2010a). Caro (2015) illustrated an application of the causal mediation model in large-scale assessment research by evaluating the mediating role of early literacy activities in the relationship between parental education and reading achievement. The methods in this paper draw extensively on this work to provide benchmarks for the causal interpretation of parental 
cognitive involvement mediation effects. The analyses use international assessment data from the TIMSS-PIRLS 2011 combined study. The data contains subject-specific information of parental cognitive involvement before the child entered school (i.e., literacy and numeracy involvement) and subject interest (i.e., reading and mathematics) for the same sample of students in each education system.

\section{Achievement motivation and subject-specific interest}

Student motivation is a multidimensional construct which includes components of students' expectations for performance, value or interest ascribed to learning, and emotional or affective engagement (Guthrie et al. 2007; Pintrich and DeGroot 1990). Within social cognitive theory, these three components are an adaptation of Bandura's expectancy-value theory which focuses on the two primary components: expectancy and value (Eccles 2005; Wigfield et al. 2009). The value component is further distinguished into intrinsic value and extrinsic value (Bandura 1989; Wigfield and Eccles 2000).

The distinction between intrinsic and extrinsic motivation for learning plays a dominant role in the conceptualisation of motivation constructs (Schiefele et al. 2012). Extrinsic motivation is derived from external incentives, such as obtaining a good grade in school, whereas intrinsic motivation is derived from enjoyment and interest in a specific topic. Studies find a weak association between extrinsic motivation and student learning, but a positive association between intrinsic motivation and student learning, which is partly explained by greater persistence and intensity of activities conductive to learning (Schiefele et al. 2012; Schunk et al. 2008).

Enjoyment and interest are fundamental for intrinsic motivation (Eccles 2005). Subject-specific interest and object-specific intrinsic motivation are closely overlapping concepts (Schiefele et al. 2012). Both actions triggered by intrinsic motivation and subject-specific interest are characterised by enjoyment and individual valuing (Frenzel et al. 2010). Because subject-specific interest leads to adequate use of learning strategies and deep-level learning it is viewed as conductive to student engagement and learning (Retelsdorf et al. 2011; Schiefele 1996). Students are expected to become more motivated in learning if they value, are interested, and enjoy the subject studied (Meece et al. 2006; Schiefele 2009; Skinner et al. 2008).

Achievement motivation levels vary significantly across cultures (Chiu and Chow 2010; Van de Vijver 2015). For example, different cultural values may promote collectivist interests (e.g. Hong Kong), individualistic interests (e.g., New Zealand), hierarchical relationships (e.g., Russia) and egalitarian relationships (e.g., Sweden). In turn, cultural values acquired through socialisation shape students' beliefs and behaviours relating to achievement motivation. For instance, there is evidence that the association between extrinsic motivation and academic achievement is stronger in collectivist and egalitarian societies (Chiu and Chow 2010).

\section{Subject interest effects on learning}

Students' subject interest is likely amongst the most important conditions for a lifelong learner. A number of studies on intrinsic motivation indicate that students' subject interest is positively related to student achievement even after controlling for student's intelligence or prior knowledge (McElvany et al. 2008; Retelsdorf et al. 2011; Schiefele et al. 
2012; Taboada et al. 2009; von Maurice et al. 2014). Although most studies have examined the influence of intrinsic motivation on student achievement, the causal direction of this relationship is not necessarily unidirectional from a theoretical viewpoint and evidence of reciprocal effects has been reported in few studies (McElvany et al. 2008; Schaffner et al. 2016; Schiefele et al. 2012).

Research points to different mechanisms for the effect of intrinsic motivation on student achievement, including greater effort in learning, use self-regulation strategies, reading breath and amount, resilience and engagement in the classroom (Deci and Ryan 2002; Greeneet al. 2004; Pintrich and De Groot 1990; Schaffneret al. 2013; Schiefele et al. 2012; Schultz 1993). Students with greater subject interest tend to pose and answer questions, look for new knowledge and stimulating educational environments, whereas less motivated students represent a challenge for the work of educators (Frenzel et al. 2010). International assessment studies too show that students with higher motivational dispositions achieve on average higher reading and mathematics scores across a range of countries (Kirsch et al. 2003; Mullis et al. 2012a, b; OECD 2013b). Further, PISA results suggest that student motivation can partly compensate for a low socio-economic background (Kirsch et al. 2003; Kriegbaum and Spinath 2016).

Meta-analysis reported a correlation of 0.30 between subject interest and academic achievement (Schiefele et al. 1992). The size of the correlation is almost the same than for the correlation of family SES and academic achievement (Sirin 2005). But unlike the family SES attribute, student motivation is viewed as being more amenable to school interventions (Appleton et al. 2006; Jimmerson et al. 2003). In part, that is one reason for the attractiveness of the study of student interest. Furthermore, subject interest appears to be more strongly related to deep-level learning than to surface-level learning. And associations with learning appear to be independent from prior achievement or ability (Schiefele 1996).

\section{Antecedents of subject interest}

Student subject interest results from complex and dynamic interactions between students, parents, and schools. Self-determination theory postulates that interactions that fulfil students' psychological needs for autonomy, competence, and social relatedness contribute to positive orientations towards learning (Deci and Ryan 2012; Schiefele 2004). For instance, positive interactions with teachers that promote students' autonomy and explain the relevance of lessons to every day's life are related to higher motivation and active participation in the classroom (Birch and Ladd 1998; Gutman and Sulzby 2000; Pianta et al. 2012). The importance of autonomy for intrinsic motivation and subject interest appears to be universal across different cultures (Chirkov and Ryan 2001; Chirkov et al. 2011; Marbell and Grolnick 2013; Wigfield et al. 2015).

The literature has identified different individual and teacher factors related to subject motivation. Individual factors such as academic values and achievement self-beliefs have shown to influence student engagement and academic achievement (Deci 1992; Eccles et al. 1998; Pintrich 2003; Pintrich and Schunk 2003; Reeve 2005). Teachers can influence student motivation in different ways (e.g., Mottet et al. 2006). Student-teacher relationships characterised by closeness and support (Little and Kobak 2003; Midgley et al. 1989; Pianta et al. 2012) and promoting students' autonomy (e.g., Hardre and 
Reeve 2003; Jang et al. 2007) tend to foster student motivation. On the contrary, teachers' false expectations can become self-fulfilling prophecies. Research has also found that teacher's enjoyment and confidence in teaching (Martin 2006) and teacher communication with parents (Kraft and Dougherty 2013) contribute to increasing student motivation.

The majority of studies on the precursors of student motivation have focused on individual and teacher factors. The influences of families and particularly family SES has been studied less frequently.

\section{Parental influences: family SES and parental cognitive involvement}

Parents play a role in student motivation directly via parental relationships with children and indirectly through interactions with schools and teachers. Parental influences on student motivation are channelled through effects on student's competence, autonomy, and social relatedness. For example, parents can influence children's competence, autonomy, and social relatedness with high academic expectations of student's competence and by providing resources that facilitate social relations and autonomy (Fan and Williams 2010; Grolnick et al. 2009; Wigfield et al. 2015). Parental involvement and autonomy support can foster motivational resources and enable children to cope with academic failure (Raftery-Helmer and Grolnick 2015; Wong 2008).

Three forms of parental involvement have been related to student motivation (Grolnick and Slowiaczek 1994): behavioural involvement (e.g., participating in school meetings), cognitive involvement (e.g., early literacy and numeracy stimulating activities), and personal involvement (e.g., academic expectations and interest in school issues). The quality of parent-child interactions is particularly important for achievement motivation (Bempechat and Shernoff 2012). But parents' possibilities for providing time and emotional resources are constrained by their SES (Bempechat and Shernoff 2012; McLanahan 2004; Wigfield et al. 2015).

Parental education and income levels are positively related to the quality and intensity of home learning experiences. Low SES families lack economic resources and parental education levels for translating resources into experiences that stimulate curiosity and intrinsic motivation in children (Bempechat and Shernoff 2012; Van Steensel 2006; Wigfield et al. 2015). Many low SES families also lack time and resources for school involvement, for example, attending school events (Bempechat and Shernoff 2012). Further, stressful events, more likely present in low SES families, tend to affect negatively the family environment and act in detriment of student motivation through, for example, lower parental responsiveness, social support, and emotional resources available for children (Grolnick et al. 2009). Stressful events in low SES families especially undermine mothers' ability to support children's motivation.

Higher SES families tend to possess greater cultural (e.g., classic literature, works of art) and educational resources (e.g., books, DVDs and other media material) at home and are more likely to engage in cognitive stimulating activities with children during the early years in part because of their higher education levels (Caro 2015; Grolnick and Slowiaczek 1994). But rather than the influence of static cultural and educational resources, research shows that parent-child cultural interactions and the dynamic aspect 
of early cognitive stimulation is the main driver of intrinsic motivation and achievement (Gottfried et al. 2015; Tramonte and Willms 2010; Neuman et al. 2014).

Parental cognitive involvement in early childhood such as time invested in shared book reading (e.g., Gottfried et al. 2015), storytelling (e.g., Snow and Dickinson 1990; Weigel et al. 2006), learning the alphabet, numbers, and letters (e.g., Parker et al. 1999), playing rhyming and math games (e.g., Baker et al. 1995; LeFevre et al. 2009; Weigel et al. 2006), and access to cognitively stimulating toys and books (e.g., Gottfried et al. 1998) set the stage for children's cognitive and intrinsic motivation development. Although there is variability in the quality of early activities both across and within SES groups, there is evidence that, in general, children from lower SES families experience less developmentally enhancing activities at home, exposure to books, reading, and verbal interactions with parents in comparison to higher SES children (e.g., Niklas and Schneider 2013; Evans et al. 2000, Gustafsson et al. 2013; Raikes et al. 2006). And that parental cognitive stimulation affects student intrinsic motivation above and beyond the effect of SES (Gottfried et al. 1998).

Cognitive home stimulation (e.g., provision of educational and intellectual activities such as lessons, political and social discussions, and visits to libraries and museums) has been found to positively impact academic intrinsic motivation beyond SES (Gottfried et al. 1998). Interest and enjoyment are fostered to a substantial degree through the students' exposure to and experiences with cognitively stimulating learning activities and the provision of learning materials (Gottfried et al. 1998). Socially disadvantaged children are often deprived of these experiences within their home environments. Motivational characteristics thus represent another weight on the social disadvantage of these children that further negatively affects their academic achievement (Schultz 1993).

It is therefore hypothesised that family SES influences student subject interest via its effect on parental cognitive involvement. Namely, that parental cognitive involvement mediates the association between family SES and student motivation. Further, parental cognitive involvement is expected to affect student motivation directly beyond its influence via family SES.

\section{Methods}

\section{Data}

Data is sourced from the combined TIMSS-PIRLS 2011 study for students in 4th grade (Martin and Mullis 2013). TIMSS-PIRLS 2011 is the first time both studies are administered in the same year, which allow us to compare comprehensive measures of reading and mathematics for the same students as well as to relate academic achievement to student and family characteristics. Sampling was conducted in two stages: schools were sampled in first stage and intact classes in second stage. Twenty-eight education systems with complete data in at least $70 \%$ of the SES constituent items were selected for the analysis: Azerbaijan, Austria, Chinese Taipei, Croatia, Czech Republic, Finland, Georgia, Hong Kong, Hungary, Iran, Ireland, Italy, Lithuania, Malta, Norway, Poland, Portugal, Romania, Russian Federation, Singapore, Slovak Republic, Slovenia, Spain, Sweden, United Arab Emirates, United Arab Emirates (Dubai), United Arab Emirates (Abu Dhabi), and Canada (Quebec). The total sample of students in the original sample and analytic sample, the percentage of missing data, correlation matrices, and descriptive statistics are presented Tables 1, 2 and 3 (see Appendix A). 
Variables

\section{Student subject interest}

PIRLS and TIMSS developed two scales reflecting interest in subjects: Students Like Learning Mathematics and Students Like Reading. These scales are referred to as student mathematics interest and students reading interest. The mathematics scale is based on student responses to the following Likert-type items $(1=$ agree a lot, $2=$ agree a little, 3 = disagree a little, 4 disagree a lot): "I enjoy learning mathematics", "I wish I did not have to study mathematic", "Mathematics is boring", "I learn many interesting things in mathematics", and "I like mathematics". The reading scale was created based on students responses to eight statements. In six statements students indicated their degree of agreement (categories as above): "I read only if I have to", "I like talking about what I read with people", "I enjoy reading", "I think reading is boring", "I would be happy of someone gave me a book as a present", "I would like to have more time for reading". In two statements students indicated how often they were doing the following $(1=$ every day or almost every day, $2=$ once or twice a week, $3=$ once or twice a month, $4=$ never or almost never): "I read for fun" and "I read things that I choose myself".

\section{Parental cognitive involvement}

PIRLS and TIMSS developed two scales reflecting cognitive involvement in subjects: Early Literacy Activities and Early Numeracy Activities. We refer to these scales as parental literacy involvement and parental numeracy involvement, respectively. The Parental Literacy Involvement scale is based on parents' responses to the following activities with the child before he/ she entered school on a Likert-type scale $(1=$ never or almost never, $2=$ sometimes, $3=$ often): "read books", "tell stories", "sing songs", "play with alphabet toys", "talk about things you had done", "talk about what you have read", "play word games", "write letters or words", and "read aloud signs and labels with the child". The Parental Numeracy Involvement scale is based on parents responses to the following activities with the child before he/she entered school on a Likert-type scale ( $1=$ never or almost never, $2=$ sometimes, $3=$ often): "say counting rhymes or sing counting songs", "play with number toys (e.g., blocks with numbers)", "count different things", "play games involving shapes (e.g., shape sorting toys, puzzles)", "play with building blocks or construction toys", and "play board games or card games".

\section{Family SES}

Parental education, parental occupational status, and home possessions are combined into a single family SES scale using a principal component analysis. Parental education and parental occupational status are measured with the maximum level of education and maximum score in occupational status for either parent. Mother's and father's levels of education are self-reported according to the following categories: $1=$ some primary, lower secondary or no schooling, $2=$ lower secondary, $3=$ upper education, $4=$ post-secondary but not university, $5=$ university or higher. Mother's and father's self-reported occupations were converted into occupational status scores following Caro and Cortés (2012). Parental occupation questions followed a categorical approach including following options along with descriptors: (a) has never worked for pay; (b) small business owner; (c) clerk; (d) service or sales worker; (e) skilled agricultural or fishery worker; (f) craft or trade worker; (g) plant or machine operator; (h) general laborers; (i) corporate manager or senior official; 
(j) professional; and (k) technician or associate professional. Job categories and descriptors were mapped into the International Socioeconomic Index of Occupational Status (ISEI) scores using the scoring scheme proposed by Ganzeboom et al. (1992).

Home possessions (i.e., computer, study desk, own room, and Internet connection) reported by students were converted into a single scale with a Rasch model. SES was scaled to have a mean of 0 and a standard deviation of 1 across education systems. The distribution of family SES by education system is presented in Fig. 5 (see Appendix A).

\section{Control variables}

Control variables related to family SES and parental cognitive involvement were reported by parents: student's pre-school attendance $(0=$ no pre-school, $1=1$ year or less, $2=$ more than 1 year, $3=3$ years or more), the Parents Like Reading Scale, the number of books at home excluding magazines, newspapers or children's books $(0=0-10,1=11-25,2=26-100$, $3=101-200,4=$ more than 200), and the number of children's books at home excluding children's magazines or school books $(0=0-10,1=11-25,2=26-50,3=51-100$, and 4 $=$ more than 100). The Parents Like Reading Scale reflected parental agreement $(1=$ agree a lot, $2=$ agree a little, $3=$ disagree a little, $4=$ disagree a lot) with the following Likert-type items: "I read only if I have to", "I like talking about what I read with other people", "I like to spend my spare time reading", "I read only if I need information", "Reading is an important activity in my home", "I would like to have more time for reading", and "I enjoy reading".

TIMSS and PIRLS scales were developed with IRT partial credit models and were scaled to have a mean score of 10 and a standard deviation of 2 across education systems (Mullis et al. 2012).

\section{Mediation model}

The analysis adopted a causal mediation approach (Caro 2015; Imai et al. 2010a, b). Causal mediation analysis represents the integration of traditional mediation analysis (Baron and Kenny 1986; MacKinnon 2008) and the potential outcomes framework (Holland 1986; Rubin, 1974). It establishes benchmarks for interpreting mediation results in causal terms by analysing the sensitivity of mediation effect estimates to the presence of unobserved confounders (Caro 2015).

The mediation model is presented in Fig. 1. The outcome is subject-specific interest $(Y)$, the treatment is family SES $(T)$, and the mediator is subject-specific parental cognitive

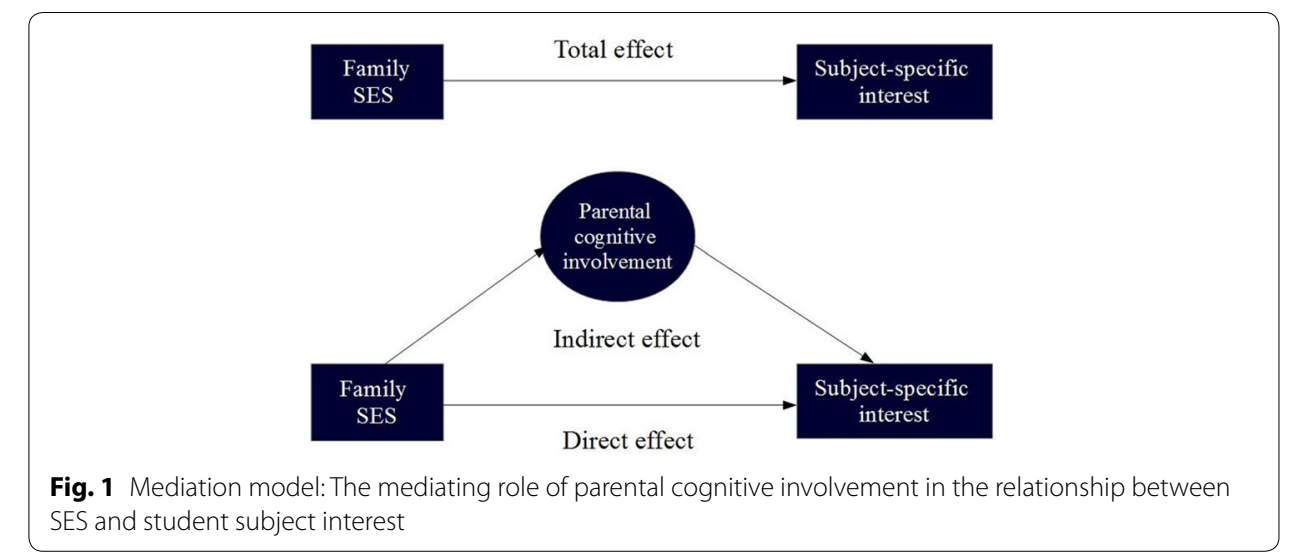


involvement reported retrospectively by parents $(M)$. Mediation conditions assume that family SES is significantly related to student interest, the total effect, and that family SES effects on student interest reduce once parental cognitive involvement is included in the model. That is, family SES has an indirect effect on the outcome through the mediator of parental cognitive involvement. Further, it is assumed that the mediator precedes the outcome in chronological order and that the treatment precedes the mediator (Kraemer et al. 2001). It is argued that retrospective data of parental cognitive involvement and relatively time-invariant family SES data make mediation assumptions plausible.

For each student $i$, two potential outcomes for the outcome and mediator are considered in the causal mediation framework. Consider, for simplicity, two treatment conditions, assignment to a high SES family $(T=1)$ and assignment to a low SES family, the control condition $(T=0)$, and not a continuous SES scale as in our data. One potential outcome is subject interest resulting from the treatment of being in a high SES family, $Y_{i}(1)$, and another potential outcome is attributed to the control condition of coming from a low SES family, $Y_{i}(0)$. The difference between both outcomes, $Y_{i}(1)-Y_{i}(0)$, is the individual treatment effect. Equally, the mediator has two potential outcomes for each student, $M_{i}(1)$ and $M_{i}(0)$, the level of parental cognitive involvement for a student in a high and low SES family, respectively. Clearly, it is not possible in practice to observe both outcomes for the same student, $i$. There is a counterfactual, for example the student interest outcome in a low SES family for a student from a high SES family. In this case, $Y_{i}(1)$ and $M_{i}(1)$ are observed but $Y_{i}(0)$ and $M_{i}(0)$ are not.

While it is not possible to identify treatment effects at the individual level, average treatment effects can be estimated when participants are randomly assigned to treatment and control conditions or with methodologies that resemble randomised experiments. Similarly, causal mediation analysis produces evidence of average mediation effects and establishes benchmarks for interpreting mediation effects causally. Causal mediation analysis is represented by the following equations,

$$
\begin{aligned}
& Y_{i}\left(T_{i}, M_{i}\left(T_{i}\right)\right)=\alpha_{1}+\beta_{1} T_{i}+\xi_{1}^{T} X_{i}+\varepsilon_{i 1} \\
& M_{i}\left(T_{i}\right)=\alpha_{2}+\beta_{2} T_{i}+\xi_{2}^{T} X_{i}+\varepsilon_{i 2} \\
& Y_{i}\left(T_{i}, M_{i}\left(T_{i}\right)\right)=\alpha_{3}+\beta_{3} T_{i}+\gamma M_{i}+\xi_{3}^{T} X_{i}+\varepsilon_{i 3}
\end{aligned}
$$

where $\varepsilon_{i 1} \sim N\left(0, \sigma_{1}\right), \varepsilon_{i 2} \sim N\left(0, \sigma_{2}\right)$, and $\varepsilon_{i 3} \sim N\left(0, \sigma_{3}\right) . Y_{i}(t, m)$ is used to denote the potential outcome and $Y_{i}\left(T_{i}, M_{i}\left(T_{i}\right)\right)$, the observed outcome (i.e., subject-specific interest) given the treatment $T$ (i.e., family SES) and the mediator $M$ (i.e., parental cognitive involvement). Control variables are represented by $X_{i}$. Total treatment effects are captured by $\hat{\beta}_{1}$, average direct effects (ADE) by $\hat{\beta}_{3}$, and mediation effects by $\hat{\beta}_{2} \hat{\gamma}$ or $\hat{\beta}_{1}-\hat{\beta}_{3}$.

Average causal mediation effects (ACME) are represented by

$$
\bar{\delta}(t)=E\left[Y_{i}\left(t_{i}, M_{i}(1)\right)-Y_{i}\left(t_{i}, M_{i}(0)\right)\right]
$$

ACME captures changes in student interest that would occur if parental cognitive involvement change from the value observed in the control condition (i.e., low SES) to the value observed under the treatment condition (i.e., high SES), while holding the treatment constant. $\hat{\beta}_{2} \hat{\gamma}$ is a valid estimate of the population $\mathrm{ACME}, \bar{\delta}(t)$ if the sequential 
ignorability assumption is met (Imai et al. 2010b): (1) the treatment is independent of potential outcomes and potential mediators given observed confounders (i.e., treatment assignment is assumed to be ignorable) and (2) the mediator is ignorable given the actual treatment status and confounders. Regression models control for confounders $\left(X_{i}\right)$ related to the mediator, treatment, and outcome in order to satisfy this assumption. This assumption, however, cannot be verified with the data and therefore sensitivity analysis is conducted to evaluate its plausibility.

\section{Sensitivity analysis}

Sensitivity analysis evaluates the variability of ACME estimates to departures from the sequential ignorability assumption (Imai et al. 2010b). It examines the extent to which violations of this assumption lead to different results. If mediation results are sensitive to slight violations of the sequential ignorability assumption, mediation results cannot be interpreted as ACME.

For example, Fig. 2 shows sensitivity analysis in Romania for ACMEs of parental literacy involvement in the relationship between family SES and student reading interest. The $\mathrm{x}$-axis represents values in the sensitivity parameter, $\rho$, and the $\mathrm{y}$-axis average causal mediation effects. The sensitivity parameter, $\rho$, measures the correlation between the error in the mediation model, $\varepsilon_{i 2}$, and the error in the outcome model, $\varepsilon_{i 3}$ (see Eqs. 2 and 3). This correlation arises if unobserved confounders affect both mediator and outcome variables, because these variables are part of the two error terms. The sequential ignorability assumption means that $\rho$ is zero. The dashed horizontal line represents ACMEs under the sequential ignorability assumption, that is, $\hat{\beta}_{2} \hat{\gamma}$. Sensitivity analysis evaluates the extent to which $\hat{\beta}_{2} \hat{\gamma}$ changes for different values of $\rho$, that is, when unobserved confounders potentially introduce bias in the estimation of ACME. Steep curves indicate that ACMEs quickly depart from the sequential ignorability assumption under the presence of confounders.

\section{Model estimation}

Causal mediation and sensitivity analysis were performed by education system using the R package 'mediation' (Tingley et al. 2014). Model estimates of Eqs. 1, 2, and 3 take into account sampling weights but not the multilevel structure of the data, because current implemented procedures cannot handle sensitivity analysis for multilevel models. The data was centred around the school mean to purge differences between schools and capture

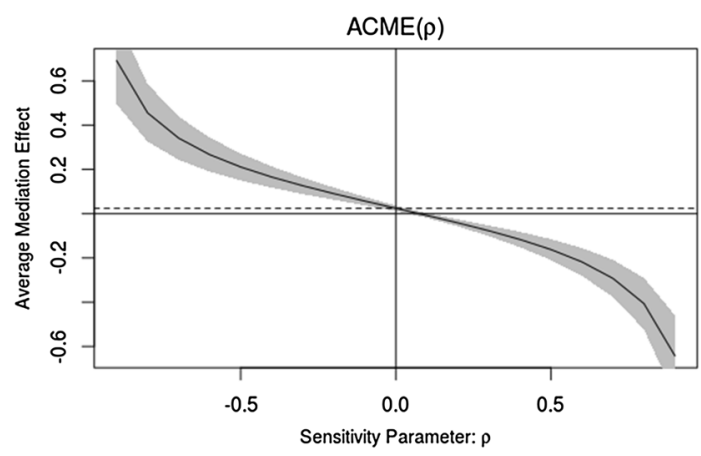

Fig. 2 Sensitivity analysis of parental cognitive mediation effects in Romania 
purely differences between students in family SES, parental cognitive involvement, and student interest within the school.

\section{Results}

Table 2 in Appendix A records correlations between family SES, parental cognitive involvement, and student interest. On average, the correlation between family SES and student interest is small: 0.04 for mathematics interest and 0.10 for reading interest across education systems. The average correlation between family SES and parental cognitive involvement scales across education systems is slightly larger: 0.16 for parental literacy involvement and 0.13 for parental numeracy involvements. Although the positive correlations are consistent with the causal direction postulated by our mediation model, the size of average correlations provide weak evidence of mediation effects. There is, however, significant variation across education systems. For example, correlations between family SES and parental cognitive involvement are around is 0.24 in Chinese Taipei and 0.28 in Romania, whereas correlations between family SES and parental numeracy involvement are 0.06 in Finland and 0.02 in Czech Republic. Correlations were positive across countries but very low. Causal mediation analysis offers stronger evidence of statistical significance of mediation effects after controlling for confounders.

Figures 3 and 4 summarise causal mediation results for the mediating role of parental cognitive involvement in the relationship between family SES and subject-specific interest. Point estimates (dots) and 95\% confidence intervals (solid lines) for the average causal mediation effect (ACME) of parental cognitive involvement, $\hat{\beta}_{2} \hat{\gamma}$, the average direct effect (ADE) of family SES, $\hat{\beta}_{3}$, and total effect of family SES, $\hat{\beta}_{1}$, are displayed. Model parameters were defined in Eqs. 1-3. Estimates are in the scale of the dependent variable of subject interest, that is, a mean score of 10 and a standard deviation of 2 across education systems. The total family SES effect, for example, can be interpreted as variation in subject interest for one unit change in family SES. The parental literacy involvement mediating mechanism for reading interest is presented in Fig. 3 and the parental numeracy involvement mediating mechanism for mathematics interest is presented in Fig. 4. The data underpinning Figs. 3 and 4 is presented in Table 4. In addition to total, direct, and mediating SES effects, Table 4 records the percentage of the total family SES effect mediated by the parental literacy and numeracy involvement mechanism.

Figure 3 shows family SES direct, total, and parental literacy involvement mediating effect on student reading interest. The total effect of family SES is significant in 15 education systems out of 28 (see Table 4). The parental literacy involvement mediating mechanism is statistically significant in 11 education system (see Table 4): Azerbaijan, Canada (Quebec), Chinese Taipei, Finland, Ireland, Portugal, Romania, Singapore, United Arab Emirates, Abu Dhabi, and Dubai. The percentage of the SES effect mediated by parental literacy involvement ranges from 3.74\% in Dubai to $21.01 \%$ in Singapore.

(See figure on next page.)

Fig. 3 Family SES and student reading interest: total, direct, and parental literacy involvement mediating association. Note. Black dots represent point estimates and solid lines $95 \%$ confidence intervals. ACME is the average causal mediation effect $\hat{\beta}_{2} \hat{\gamma}_{;} A D E$ is the average direct effect of family SES $\hat{\beta}_{3}$; and Total is the total effect of family SES $\hat{\beta}_{1}$ 

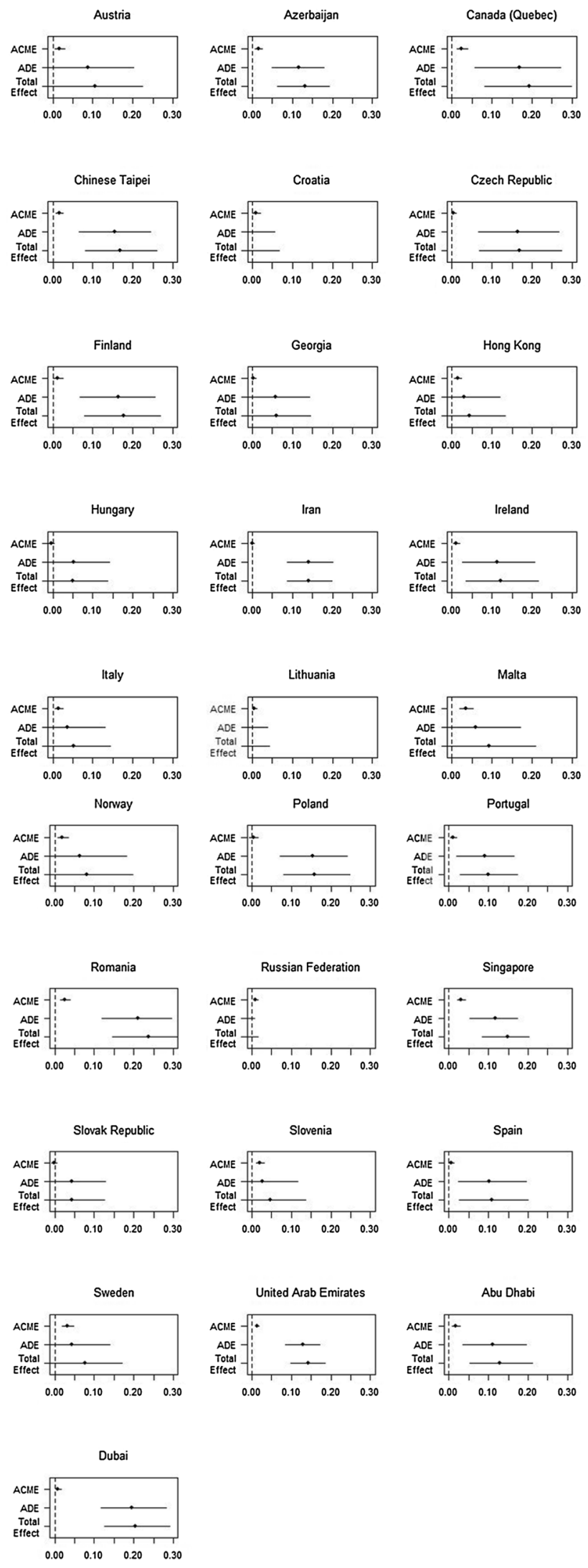

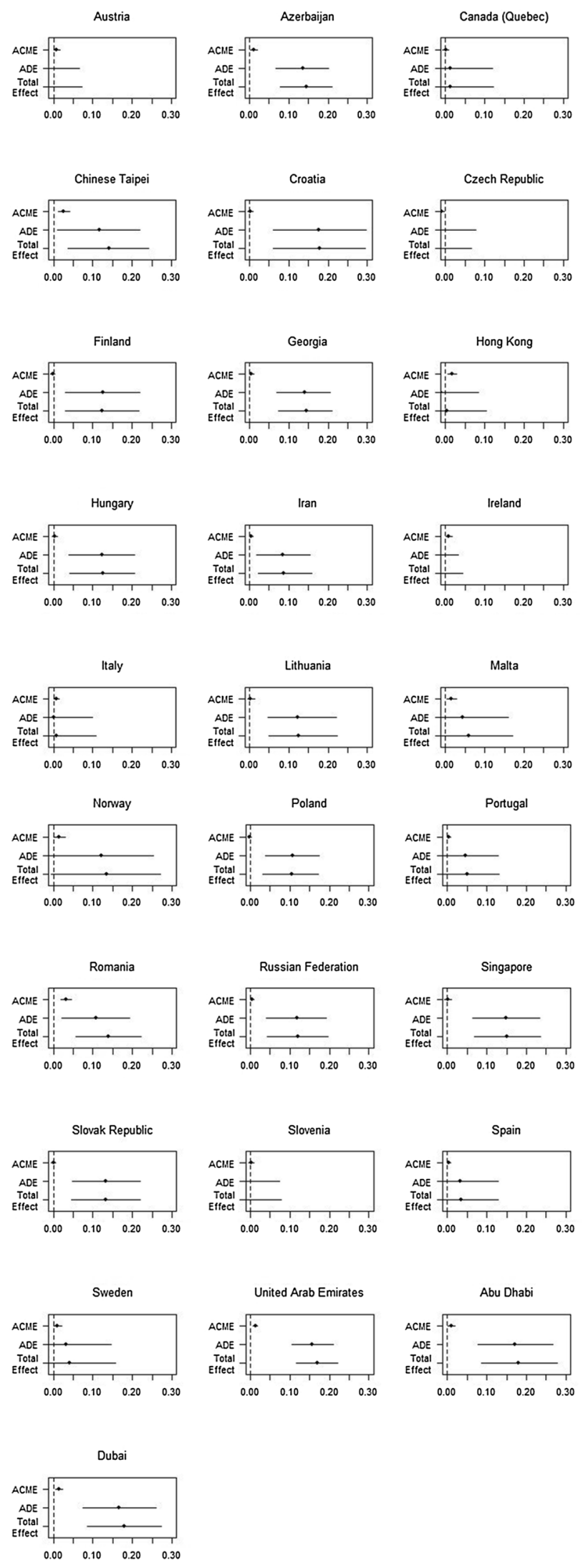
(See figure on previous page.)

Fig. 4 Family SES and student mathematics interest: total, direct, and parental numeracy involvement mediating association. Note. Black dots represent point estimates and solid lines $95 \%$ confidence intervals. $A C M E$ is the average causal mediation effect $\hat{\beta}_{2} \hat{\gamma} ; A D E$ is the average direct effect of family SES $\hat{\beta}_{3}$; and Total is the total effect of family SES $\hat{\beta}_{1}$

In education systems where the total SES effect is significant the largest part of the SES effect is a direct effect and the parental literacy involvement mechanism explains a small proportion of the total SES effect. That is, other mechanisms beyond parental literacy involvement explain the family SES effect on student reading interest.

Figure 4 shows family SES direct, total, and parental numeracy involvement mediating effect on student mathematics interest. The total effect of family SES is significant in 16 education systems out of 28 (see Table 4). The parental numeracy involvement mediating mechanisms is statistically significant in 7 education system (see Table 5): Azerbaijan, Chinese Taipei, Iran, Romania, United Arab Emirates, Abu Dhabi, and Dubai. The percentage of the SES effect on student mathematics interest mediated by parental numeracy involvement ranges from 3.92\% in Iran to $22.19 \%$ in Romania. But the parental numeracy involvement mechanism cannot fully explain the total family SES in any education system. Compared to the direct effect of SES, the mediating effect explains a smaller proportion of the total effect of SES. That is, other mechanisms not represented by the data explain the total effect of family SES on student mathematics interest in education systems where the total family SES was statistically significant.

On average, the correlation between parental literacy and numeracy involvement is relatively high across education systems $(\rho=0.66$; see Table 2$)$. But because average correlations between student interest and family SES tend to be larger for student reading interest $(\rho=0.10)$ and the correlation with family SES is larger for parental literacy involvement $(\rho=0.16)$ than for parental numeracy involvement $(\rho=0.13)$, stronger evidence of mediating effects is found for the SES mediating effect of parental literacy involvement on student reading interest (see Table 2).

Figures 6 and 7 in Appendix B present sensitivity analysis for mediating effects in Figs. 2 and 3, respectively. Overall, average causal mediation effects displayed in Figs. 2 and 3 are small and quickly become zero for slight changes in sensitivity parameters. That is, mediation effects are strongly affected by violations of the sequential ignorability assumption.

Up to this point results concentrated on family SES direct and indirect effects. Additionally, Table 5 reports regression coefficients of parental cognitive involvement for regressions of student subject interest, on parental cognitive involvement, SES, and confounders. Results show consistently that parental cognitive involvement is positively associated with subject interest independently of SES and confounders. Particularly, the association between reading subject interest with parental literacy involvement is positive and significant in every education system. 


\section{Discussion}

This study has evaluated the mediating effect of parental cognitive involvement in the relationship between family SES and students' subject interest using matched international data from TIMSS-PIRLS 2011. The study has aimed to contribute to research on equity in education and educational research more generally in different ways.

Educational research has been criticised for concentrating almost exclusively on academic achievement outcomes and for the lack of cross-cultural perspectives (Creemers and Kyriakides 2008). The study of family SES associations with subject-specific interest for students living in very different cultural and economic contexts contributes to addressing this criticism. The literature on motivation has largely studied influences of individual and teacher factors, but evidence of family influences is scarce despite theoretical arguments for family SES and parental cognitive involvement influences (Grolnick and Slowiaczek 1994; Raftery-Helmer and Grolnick 2015). This study contributes international evidence of these mechanisms to the knowledge base of educational research.

The analyses look at student interest in two different subjects, reading and mathematics, for the same sample of students in each education system. To the extent that students' experiences and outcomes vary by subject area, the subject-specificity of intrinsic motivation related outcomes and mediating mechanisms of parental literacy involvement and parental numeracy involvement seems appropriate. The study of student motivation in primary school is particularly relevant in light of research suggesting that students' intrinsic motivation for learning declines as they get older, especially for low SES students (Frenzel et al. 2010; Gottfried et al. 2007; Unrau and Schlackman 2006; Wigfield et al. 2015).

The results point to a weak association between family SES and student subject interest. While in some education systems students from higher socio-economic backgrounds report being more interested in reading and mathematics than students from less affluent families, many socio-economically disadvantaged students report being motivated despite family SES barriers. There is, however, significant variation between education systems. For example, family SES is positively related to student reading interest in the United Arab Emirates, Romania, Finland, Czech Republic, Canada (Quebec), but it is not in Croatia, Lithuania, and the Russian Federation. Likewise, family SES is positively related to student mathematics interest in United Arab Emirates, Romania, Slovak Republic, Croatia, Chinese Taipei, Azerbaijan, but it is not in Austria, Czech Republic, Hong Kong, Ireland, and Slovenia.

Associations between family SES and students' subject interest are not affected by school socio-economic stratification because variables were centred around the school mean to purge differences between schools and capture purely within school differences. The results suggest that socio-economically disadvantaged students are not necessarily less motivated and that in some education systems many disadvantaged students are clearly resilient in terms of their interest in reading and mathematics, at least if guided by student self-reports. But results could be affected by social desirability. Research suggests that students from low SES families and in less developed countries tend to report higher motivation for social desirability reasons (Van de Vijver 2015). If that is the case, the association between family SES and interest in reading and mathematics is underestimated in our analysis. And it is possible that family SES plays a more important role 
in shaping students' intrinsic motivation across education systems than expected from observed associations with students' and parents' self-reports.

Across education systems, parents from higher SES families slightly tended to be more cognitively involved in children's learning before the beginning of school than parents in lower SES families. Higher SES parents tended to be more cognitively involved in both literacy and numeracy activities with the child. For instance, higher SES parents more often read books, told stories, sang songs, played word games, played with number toys, and played games involving shapes with children than lower SES parents. The association between family SES and parental cognitive involvement, however, was not strong and many parents from low SES backgrounds also reported performing these cognitive stimulating activities with children.

Parental cognitive involvement appeared to somewhat mediate SES inequalities in student subject interest in some education systems (e.g., Singapore, Romania, Chinese Taipei, Quebec, Abu Dhabi, Portugal). That is, higher SES students in these systems seemed to be more interested in learning because parents had been more cognitively involved in children's learning before they entered school. But evidence for the parental cognitive involvement mechanism was weak and significant in less than half of the education systems in the sample. Parental cognitive involvement mediation evidence was stronger for reading interest than for mathematics interest. Parental literacy involvement before the child entered school mediated significant proportions of SES differences in students' self-reported reading interest across education systems. Parental numeracy involvement less consistently mediated family SES effects on students' self-reported mathematics interest. Overall, however, sensitivity analysis indicated that parental literacy involvement and parental numeracy involvement mediation results cannot be interpreted in causal terms.

Despite insufficient support for the parental cognitive involvement mechanism in family SES effects on subject interest, results showed a direct association between parental literacy involvement and student reading interest as well as a direct association between parental numeracy involvement and student mathematics interest independently of family SES (see Table 5). Thus, apart for the potential role of parental cognitive involvement in reducing socio-economic gaps in student motivation, the results suggested that parental cognitive involvement is an effective gateway for influencing student motivation across education systems. This result is consistent with evidence showing that cognitive stimulating interactions between students, parents, and teachers promote students' interest and engagement in learning (e.g., Gottfried et al. 2015). To the extent that student subject interest is positively related to student academic achievement, cognitive stimulating activities with students could have an effect on academic achievement via student motivation, as suggested by recent research with PISA 2012 data indicating a positive and consistent relationship between teachers' cognitively activating strategies student performance in mathematics (Caro et al. 2016).

The direct association between parental cognitive involvement and student subject interest suggests that educational interventions that compensate for lack of cognitive activating experiences at home by providing children with opportunities that stimulate their curiosity and promote their interest in learning in school could positively influence students' motivation. But evidence of family influences in this paper is insufficient to derive specific recommendations for educational policy. And further research is needed to understand family influences on student motivation, the mechanisms underlying 
family SES influences, and how family influences interact with students and teachers in shaping students' motivation.

\section{Limitations}

A number of study limitations should be recognised. Motivational outcomes and parental cognitive involvement are self-reported by students and parents. Student subject interest and engagement could more appropriately be measured with observations or ratings from teachers, for example. Further, it is not clear that motivational scales can be compared across different cultures within and between countries. There could be cross-cultural validity issues, for example, due to different response styles of Likert-type items across cultures (Van de Vijver 2015). Observed responses could reflect differences in response styles rather than actual motivation dispositions. For example, research shows that Confucian cultures tend to avoid extreme values and prefer midpoint values of response scales, whereas Latin American students use more frequently extreme response categories (Harzing 2006; Van de Vijver 2015). And that students from low SES backgrounds and less developed countries tend to show more social desirability in responses (Van de Vijver 2015). Differences in subject-interest scores across countries could thus reflect this source of method bias instead of actual differences in subject interest (Artelt 2005; Buckley 2009).

Likewise, SES is not directly comparable across countries. We know from previous research that the weight of home possessions on SES is positive in developing countries but almost zero in high income countries (Caro and Cortés 2012). That is, home possessions surveyed in PIRLS do not discriminate well between higher and lower SES families in high income countries. When coupled with reports of relatively high education levels by parents, SES distributions tend to be negatively skewed, showing little variation at lower SES levels due to lack of valid SES items (e.g., Finland, Norway, the Russian Federation, Sweden, and the United Arab Emirates). Lack of variability in SES items affects the validity of our SES measure and its cross-country comparability.

Comparisons of motivational outcomes and SES scores at the country level have been avoided for this reason. Instead, findings rely on within-country results of mediation analysis. Research shows it is possible to compare across countries differences in withincountry associations with motivational outcomes (Artelt 2005). Cross-cultural validity might still represent a limitation for the comparability of associations with family SES and parental cognitive involvement scales across countries.

Another limitation is that retrospective data on parental cognitive involvement could be biased by present knowledge of the child's interests and student achievement as well as by compliance of what is expected from parents. A chronological order beginning from family SES, followed by parental cognitive involvement and ultimately student motivation has been assumed to meet mediation analysis conditions. But retrospective judgements of cognitive stimulating activities before the child entered school might not be accurate and family SES might have changed during the first school years until Grade 4 when the data was collected.

Another limitation is that causal mediation and sensitivity analysis do not take into account the multilevel structure of the data or the missing data mechanism. The implementation of causal mediation analysis in $\mathrm{R}$ is relatively new and sensitivity analysis cannot be performed in combination with multilevel modelling. Because models do not 
control for prior motivational outcomes, alternative explanations for mediation effects cannot be ruled out. It is possible for reciprocal effects to exist between motivation and parental cognitive involvement. That is, that not only parental cognitive involvement can affect student motivation but also more motivated children might seek and stimulate cognitively activating interactions with parents (Grolnick et al. 2009).

Authors' contributions

The article was fully developed by a single author. The author read and approved the final manuscript.

Acknowledgements

Not applicable.

Competing interests

The author declares that they have no competing interests.

Availability of data and materials

The datasets generated and/or analysed during the current study are available in the IEA Data Repository.

Funding

No sources of funding are declared.

\section{Appendixes}

Appendix A: Data descriptive statistics

See Tables 1, 2 and 3 and Fig. 5. 


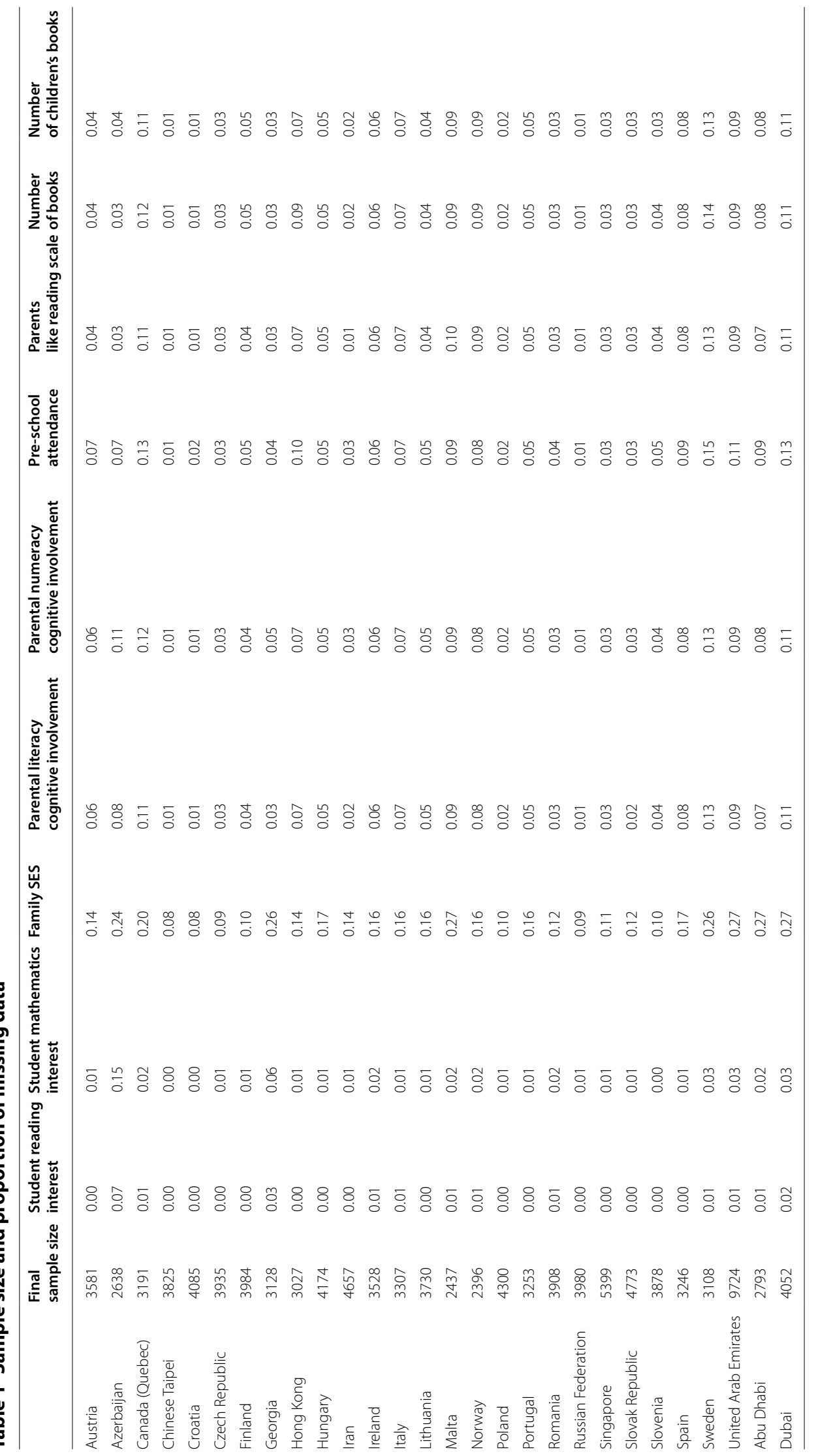




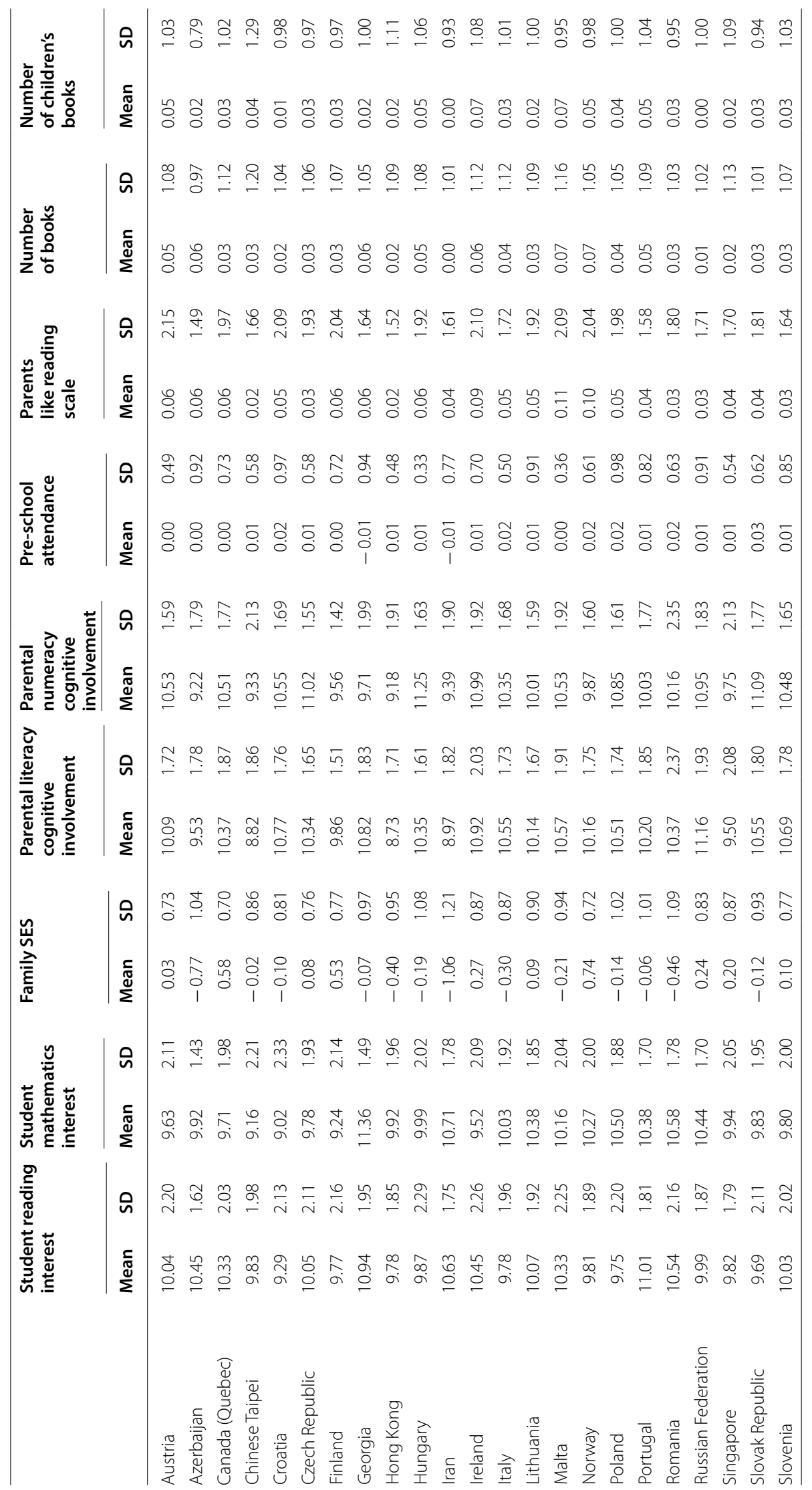




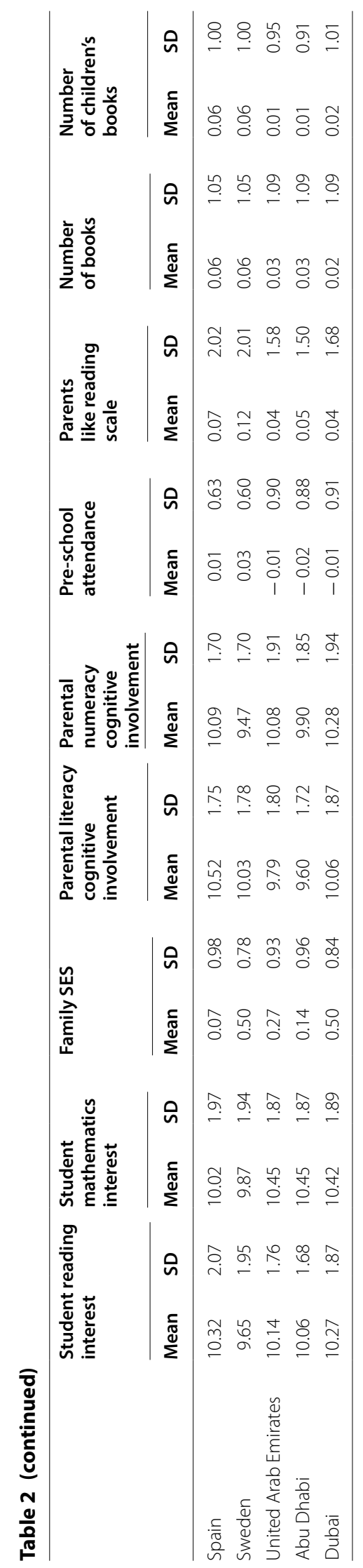


Table 3 Correlation matrix: variables included in the analysis

\begin{tabular}{|c|c|c|c|c|c|c|c|c|c|}
\hline & (a) & (b) & (c) & (d) & (e) & (f) & (g) & (h) & (i) \\
\hline \multicolumn{10}{|l|}{ Austria } \\
\hline Student reading interest (a) & 1 & 0.11 & 0.11 & 0.16 & 0.08 & -0.03 & 0.15 & 0.16 & 0.19 \\
\hline Student mathematics interest (b) & 0.11 & 1 & -0.01 & 0.02 & 0.06 & -0.02 & -0.04 & -0.02 & -0.03 \\
\hline Family SES (c) & 0.11 & -0.01 & 1 & 0.16 & 0.15 & 0.09 & 0.25 & 0.44 & 0.39 \\
\hline $\begin{array}{l}\text { Parental literacy cognitive involve- } \\
\text { ment (d) }\end{array}$ & 0.16 & 0.02 & 0.16 & 1 & 0.66 & 0.01 & 0.31 & 0.23 & 0.26 \\
\hline $\begin{array}{l}\text { Parental numeracy cognitive } \\
\text { involvement (e) }\end{array}$ & 0.08 & 0.06 & 0.15 & 0.66 & 1 & 0.04 & 0.25 & 0.19 & 0.24 \\
\hline Pre-school attendance (f) & -0.03 & -0.02 & 0.09 & 0.01 & 0.04 & 1 & 0.02 & 0.04 & 0.03 \\
\hline Parents like reading scale (g) & 0.15 & -0.04 & 0.25 & 0.31 & 0.25 & 0.02 & 1 & 0.51 & 0.38 \\
\hline Number of books at home (h) & 0.16 & -0.02 & 0.44 & 0.23 & 0.19 & 0.04 & 0.51 & 1 & 0.67 \\
\hline $\begin{array}{l}\text { Number of children books at home } \\
\text { (i) }\end{array}$ & 0.19 & -0.03 & 0.39 & 0.26 & 0.24 & 0.03 & 0.38 & 0.67 & 1 \\
\hline \multicolumn{10}{|l|}{ Azerbaijan } \\
\hline Student reading interest (a) & 1 & 0.21 & 0.07 & 0.10 & 0.05 & 0.00 & 0.08 & 0.03 & 0.05 \\
\hline Student mathematics interest (b) & 0.21 & 1 & 0.10 & 0.09 & 0.07 & -0.02 & 0.07 & 0.07 & 0.04 \\
\hline Family SES (c) & 0.07 & 0.10 & 1 & 0.17 & 0.18 & 0.08 & 0.20 & 0.33 & 0.20 \\
\hline $\begin{array}{l}\text { Parental literacy cognitive involve- } \\
\text { ment (d) }\end{array}$ & 0.10 & 0.09 & 0.17 & 1 & 0.59 & 0.08 & 0.29 & 0.22 & 0.24 \\
\hline $\begin{array}{l}\text { Parental numeracy cognitive } \\
\text { involvement }(e)\end{array}$ & 0.05 & 0.07 & 0.18 & 0.59 & 1 & 0.12 & 0.23 & 0.19 & 0.21 \\
\hline Pre-school attendance (f) & 0.00 & -0.02 & 0.08 & 0.08 & 0.12 & 1 & 0.01 & 0.07 & 0.06 \\
\hline Parents like reading scale (g) & 0.08 & 0.07 & 0.20 & 0.29 & 0.23 & 0.01 & 1 & 0.28 & 0.21 \\
\hline Number of books at home (h) & 0.03 & 0.07 & 0.33 & 0.22 & 0.19 & 0.07 & 0.28 & 1 & 0.56 \\
\hline $\begin{array}{l}\text { Number of children books at home } \\
\text { (i) }\end{array}$ & 0.05 & 0.04 & 0.20 & 0.24 & 0.21 & 0.06 & 0.21 & 0.56 & 1 \\
\hline \multicolumn{10}{|l|}{ Canada (Quebec) } \\
\hline Student reading interest (a) & 1 & 0.16 & 0.10 & 0.16 & 0.06 & 0.00 & 0.19 & 0.11 & 0.14 \\
\hline Student mathematics interest (b) & 0.16 & 1 & 0.04 & 0.02 & 0.07 & 0.01 & 0.01 & 0.01 & 0.03 \\
\hline Family SES (c) & 0.10 & 0.04 & 1 & 0.15 & 0.07 & 0.04 & 0.19 & 0.26 & 0.19 \\
\hline $\begin{array}{l}\text { Parental literacy cognitive involve- } \\
\text { ment (d) }\end{array}$ & 0.16 & 0.02 & 0.15 & 1 & 0.66 & 0.04 & 0.33 & 0.20 & 0.26 \\
\hline $\begin{array}{l}\text { Parental numeracy cognitive } \\
\text { involvement (e) }\end{array}$ & 0.06 & 0.07 & 0.07 & 0.66 & 1 & 0.05 & 0.23 & 0.13 & 0.22 \\
\hline Pre-school attendance (f) & 0.00 & 0.01 & 0.04 & 0.04 & 0.05 & 1 & 0.02 & 0.01 & 0.01 \\
\hline Parents like reading scale (g) & 0.19 & 0.01 & 0.19 & 0.33 & 0.23 & 0.02 & 1 & 0.41 & 0.26 \\
\hline Number of books at home (h) & 0.11 & 0.01 & 0.26 & 0.20 & 0.13 & 0.01 & 0.41 & 1 & 0.52 \\
\hline $\begin{array}{l}\text { Number of children books at home } \\
\text { (i) }\end{array}$ & 0.14 & 0.03 & 0.19 & 0.26 & 0.22 & 0.01 & 0.26 & 0.52 & 1 \\
\hline \multicolumn{10}{|l|}{ Chinese Taipei } \\
\hline Student reading interest (a) & 1 & 0.21 & 0.17 & 0.20 & 0.14 & 0.03 & 0.21 & 0.21 & 0.22 \\
\hline Student mathematics interest (b) & 0.21 & 1 & 0.05 & 0.07 & 0.08 & 0.00 & 0.03 & 0.04 & 0.03 \\
\hline Family SES (c) & 0.17 & 0.05 & 1 & 0.24 & 0.25 & 0.18 & 0.23 & 0.42 & 0.41 \\
\hline $\begin{array}{l}\text { Parental literacy cognitive involve- } \\
\text { ment (d) }\end{array}$ & 0.20 & 0.07 & 0.24 & 1 & 0.70 & 0.03 & 0.37 & 0.32 & 0.35 \\
\hline $\begin{array}{l}\text { Parental numeracy cognitive } \\
\text { involvement (e) }\end{array}$ & 0.14 & 0.08 & 0.25 & 0.70 & 1 & 0.04 & 0.27 & 0.26 & 0.31 \\
\hline Pre-school attendance (f) & 0.03 & 0.00 & 0.18 & 0.03 & 0.04 & 1 & 0.04 & 0.08 & 0.09 \\
\hline Parents like reading scale (g) & 0.21 & 0.03 & 0.23 & 0.37 & 0.27 & 0.04 & 1 & 0.38 & 0.32 \\
\hline Number of books at home (h) & 0.21 & 0.04 & 0.42 & 0.32 & 0.26 & 0.08 & 0.38 & 1 & 0.69 \\
\hline $\begin{array}{l}\text { Number of children books at home } \\
\text { (i) }\end{array}$ & 0.22 & 0.03 & 0.41 & 0.35 & 0.31 & 0.09 & 0.32 & 0.69 & 1 \\
\hline
\end{tabular}


Table 3 (continued)

\begin{tabular}{|c|c|c|c|c|c|c|c|c|c|}
\hline & (a) & (b) & (c) & (d) & (e) & (f) & (g) & (h) & (i) \\
\hline \multicolumn{10}{|l|}{ Croatia } \\
\hline Student reading interest (a) & 1 & 0.24 & 0.04 & 0.13 & 0.04 & -0.03 & 0.10 & 0.07 & 0.10 \\
\hline Student mathematics interest (b) & 0.24 & 1 & 0.05 & 0.04 & 0.06 & 0.00 & 0.00 & 0.02 & 0.04 \\
\hline Family SES (c) & 0.04 & 0.05 & 1 & 0.13 & 0.10 & 0.26 & 0.22 & 0.39 & 0.31 \\
\hline $\begin{array}{l}\text { Parental literacy cognitive involve- } \\
\text { ment (d) }\end{array}$ & 0.13 & 0.04 & 0.13 & 1 & 0.65 & 0.05 & 0.33 & 0.20 & 0.24 \\
\hline $\begin{array}{l}\text { Parental numeracy cognitive } \\
\text { involvement (e) }\end{array}$ & 0.04 & 0.06 & 0.10 & 0.65 & 1 & 0.06 & 0.24 & 0.16 & 0.20 \\
\hline Pre-school attendance (f) & -0.03 & 0.00 & 0.26 & 0.05 & 0.06 & 1 & 0.10 & 0.15 & 0.13 \\
\hline Parents like reading scale (g) & 0.10 & 0.00 & 0.22 & 0.33 & 0.24 & 0.10 & 1 & 0.41 & 0.29 \\
\hline Number of books at home (h) & 0.07 & 0.02 & 0.39 & 0.20 & 0.16 & 0.15 & 0.41 & 1 & 0.64 \\
\hline $\begin{array}{l}\text { Number of children books at home } \\
\text { (i) }\end{array}$ & 0.10 & 0.04 & 0.31 & 0.24 & 0.20 & 0.13 & 0.29 & 0.64 & 1 \\
\hline \multicolumn{10}{|l|}{ Czech Republic } \\
\hline Student reading interest (a) & 1 & 0.17 & 0.10 & 0.11 & 0.05 & -0.03 & 0.17 & 0.11 & 0.17 \\
\hline Student mathematics interest (b) & 0.17 & 1 & -0.02 & 0.00 & 0.05 & -0.01 & -0.01 & -0.02 & 0.00 \\
\hline Family SES (c) & 0.10 & -0.02 & 1 & 0.09 & 0.02 & 0.12 & 0.22 & 0.37 & 0.32 \\
\hline $\begin{array}{l}\text { Parental literacy cognitive involve- } \\
\text { ment (d) }\end{array}$ & 0.11 & 0.00 & 0.09 & 1 & 0.58 & -0.03 & 0.25 & 0.15 & 0.18 \\
\hline $\begin{array}{l}\text { Parental numeracy cognitive } \\
\text { involvement (e) }\end{array}$ & 0.05 & 0.05 & 0.02 & 0.58 & 1 & 0.03 & 0.15 & 0.08 & 0.14 \\
\hline Pre-school attendance (f) & -0.03 & -0.01 & 0.12 & -0.03 & 0.03 & 1 & 0.01 & 0.04 & 0.05 \\
\hline Parents like reading scale (g) & 0.17 & -0.01 & 0.22 & 0.25 & 0.15 & 0.01 & 1 & 0.44 & 0.38 \\
\hline Number of books at home (h) & 0.11 & -0.02 & 0.37 & 0.15 & 0.08 & 0.04 & 0.44 & 1 & 0.63 \\
\hline $\begin{array}{l}\text { Number of children books at home } \\
\text { (i) }\end{array}$ & 0.17 & 0.00 & 0.32 & 0.18 & 0.14 & 0.05 & 0.38 & 0.63 & 1 \\
\hline \multicolumn{10}{|l|}{ Finland } \\
\hline Student reading interest (a) & 1 & 0.17 & 0.12 & 0.17 & 0.06 & -0.05 & 0.16 & 0.14 & 0.15 \\
\hline Student mathematics interest (b) & 0.17 & 1 & 0.02 & 0.04 & 0.09 & -0.04 & 0.00 & 0.00 & 0.02 \\
\hline Family SES (c) & 0.12 & 0.02 & 1 & 0.12 & 0.06 & 0.08 & 0.21 & 0.32 & 0.27 \\
\hline $\begin{array}{l}\text { Parental literacy cognitive involve- } \\
\text { ment (d) }\end{array}$ & 0.17 & 0.04 & 0.12 & 1 & 0.66 & -0.03 & 0.29 & 0.20 & 0.24 \\
\hline $\begin{array}{l}\text { Parental numeracy cognitive } \\
\text { involvement (e) }\end{array}$ & 0.06 & 0.09 & 0.06 & 0.66 & 1 & -0.02 & 0.19 & 0.14 & 0.22 \\
\hline Pre-school attendance (f) & -0.05 & -0.04 & 0.08 & -0.03 & -0.02 & 1 & 0.01 & 0.00 & -0.05 \\
\hline Parents like reading scale (g) & 0.16 & 0.00 & 0.21 & 0.29 & 0.19 & 0.01 & 1 & 0.42 & 0.30 \\
\hline Number of books at home (h) & 0.14 & 0.00 & 0.32 & 0.20 & 0.14 & 0.00 & 0.42 & 1 & 0.55 \\
\hline $\begin{array}{l}\text { Number of children books at home } \\
\text { (i) }\end{array}$ & 0.15 & 0.02 & 0.27 & 0.24 & 0.22 & -0.05 & 0.30 & 0.55 & 1 \\
\hline \multicolumn{10}{|l|}{ Georgia } \\
\hline Student reading interest (a) & 1 & 0.27 & 0.04 & 0.06 & 0.06 & 0.00 & 0.09 & 0.03 & 0.03 \\
\hline Student mathematics interest (b) & 0.27 & 1 & 0.08 & 0.05 & 0.06 & 0.01 & 0.05 & 0.06 & 0.04 \\
\hline Family SES (c) & 0.04 & 0.08 & 1 & 0.09 & 0.17 & 0.08 & 0.19 & 0.39 & 0.33 \\
\hline $\begin{array}{l}\text { Parental literacy cognitive involve- } \\
\text { ment (d) }\end{array}$ & 0.06 & 0.05 & 0.09 & 1 & 0.65 & 0.08 & 0.26 & 0.15 & 0.19 \\
\hline $\begin{array}{l}\text { Parental numeracy cognitive } \\
\text { involvement (e) }\end{array}$ & 0.06 & 0.06 & 0.17 & 0.65 & 1 & 0.06 & 0.23 & 0.21 & 0.24 \\
\hline Pre-school attendance (f) & 0.00 & 0.01 & 0.08 & 0.08 & 0.06 & 1 & 0.01 & 0.03 & 0.03 \\
\hline Parents like reading scale (g) & 0.09 & 0.05 & 0.19 & 0.26 & 0.23 & 0.01 & 1 & 0.30 & 0.27 \\
\hline Number of books at home (h) & 0.03 & 0.06 & 0.39 & 0.15 & 0.21 & 0.03 & 0.30 & 1 & 0.62 \\
\hline $\begin{array}{l}\text { Number of children books at home } \\
\text { (i) }\end{array}$ & 0.03 & 0.04 & 0.33 & 0.19 & 0.24 & 0.03 & 0.27 & 0.62 & 1 \\
\hline
\end{tabular}


Table 3 (continued)

\begin{tabular}{|c|c|c|c|c|c|c|c|c|c|}
\hline & (a) & (b) & (c) & (d) & (e) & (f) & (g) & (h) & (i) \\
\hline \multicolumn{10}{|l|}{ Hong Kong } \\
\hline Student reading interest (a) & 1 & 0.13 & 0.09 & 0.15 & 0.10 & 0.02 & 0.14 & 0.14 & 0.19 \\
\hline Student mathematics interest (b) & 0.13 & 1 & 0.00 & 0.06 & 0.09 & 0.02 & 0.00 & -0.01 & 0.00 \\
\hline Family SES (c) & 0.09 & 0.00 & 1 & 0.18 & 0.15 & 0.06 & 0.16 & 0.29 & 0.27 \\
\hline $\begin{array}{l}\text { Parental literacy cognitive involve- } \\
\text { ment (d) }\end{array}$ & 0.15 & 0.06 & 0.18 & 1 & 0.68 & 0.09 & 0.31 & 0.26 & 0.29 \\
\hline $\begin{array}{l}\text { Parental numeracy cognitive } \\
\text { involvement (e) }\end{array}$ & 0.10 & 0.09 & 0.15 & 0.68 & 1 & 0.09 & 0.22 & 0.21 & 0.25 \\
\hline Pre-school attendance $(f)$ & 0.02 & 0.02 & 0.06 & 0.09 & 0.09 & 1 & 0.06 & 0.03 & 0.07 \\
\hline Parents like reading scale (g) & 0.14 & 0.00 & 0.16 & 0.31 & 0.22 & 0.06 & 1 & 0.30 & 0.26 \\
\hline Number of books at home (h) & 0.14 & -0.01 & 0.29 & 0.26 & 0.21 & 0.03 & 0.30 & 1 & 0.59 \\
\hline $\begin{array}{l}\text { Number of children books at home } \\
\text { (i) }\end{array}$ & 0.19 & 0.00 & 0.27 & 0.29 & 0.25 & 0.07 & 0.26 & 0.59 & 1 \\
\hline \multicolumn{10}{|l|}{ Hungary } \\
\hline Student reading interest (a) & 1 & 0.21 & 0.11 & 0.15 & 0.10 & 0.03 & 0.22 & 0.12 & 0.15 \\
\hline Student mathematics interest (b) & 0.21 & 1 & 0.08 & 0.06 & 0.09 & 0.03 & 0.04 & 0.07 & 0.07 \\
\hline Family SES (c) & 0.11 & 0.08 & 1 & 0.11 & 0.14 & 0.06 & 0.30 & 0.49 & 0.46 \\
\hline $\begin{array}{l}\text { Parental literacy cognitive involve- } \\
\text { ment (d) }\end{array}$ & 0.15 & 0.06 & 0.11 & 1 & 0.57 & 0.02 & 0.23 & 0.16 & 0.20 \\
\hline $\begin{array}{l}\text { Parental numeracy cognitive } \\
\text { involvement (e) }\end{array}$ & 0.10 & 0.09 & 0.14 & 0.57 & 1 & 0.04 & 0.19 & 0.17 & 0.24 \\
\hline Pre-school attendance (f) & 0.03 & 0.03 & 0.06 & 0.02 & 0.04 & 1 & 0.03 & 0.10 & 0.06 \\
\hline Parents like reading scale (g) & 0.22 & 0.04 & 0.30 & 0.23 & 0.19 & 0.03 & 1 & 0.41 & 0.37 \\
\hline Number of books at home (h) & 0.12 & 0.07 & 0.49 & 0.16 & 0.17 & 0.10 & 0.41 & 1 & 0.69 \\
\hline $\begin{array}{l}\text { Number of children books at home } \\
\text { (i) }\end{array}$ & 0.15 & 0.07 & 0.46 & 0.20 & 0.24 & 0.06 & 0.37 & 0.69 & 1 \\
\hline \multicolumn{10}{|l|}{ Iran } \\
\hline Student reading interest (a) & 1 & 0.35 & 0.10 & 0.08 & 0.08 & 0.02 & 0.11 & 0.07 & 0.08 \\
\hline Student mathematics interest (b) & 0.35 & 1 & 0.07 & 0.06 & 0.07 & 0.02 & 0.08 & 0.07 & 0.06 \\
\hline Family SES (c) & 0.10 & 0.07 & 1 & 0.11 & 0.12 & 0.17 & 0.15 & 0.37 & 0.26 \\
\hline $\begin{array}{l}\text { Parental literacy cognitive involve- } \\
\text { ment (d) }\end{array}$ & 0.08 & 0.06 & 0.11 & 1 & 0.67 & 0.16 & 0.31 & 0.17 & 0.22 \\
\hline $\begin{array}{l}\text { Parental numeracy cognitive } \\
\text { involvement (e) }\end{array}$ & 0.08 & 0.07 & 0.12 & 0.67 & 1 & 0.13 & 0.28 & 0.17 & 0.21 \\
\hline Pre-school attendance (f) & 0.02 & 0.02 & 0.17 & 0.16 & 0.13 & 1 & 0.06 & 0.10 & 0.14 \\
\hline Parents like reading scale (g) & 0.11 & 0.08 & 0.15 & 0.31 & 0.28 & 0.06 & 1 & 0.27 & 0.22 \\
\hline Number of books at home (h) & 0.07 & 0.07 & 0.37 & 0.17 & 0.17 & 0.10 & 0.27 & 1 & 0.46 \\
\hline $\begin{array}{l}\text { Number of children books at home } \\
\text { (i) }\end{array}$ & 0.08 & 0.06 & 0.26 & 0.22 & 0.21 & 0.14 & 0.22 & 0.46 & 1 \\
\hline \multicolumn{10}{|l|}{ Ireland } \\
\hline Student reading interest (a) & 1 & 0.17 & 0.14 & 0.16 & 0.07 & 0.01 & 0.18 & 0.17 & 0.22 \\
\hline Student mathematics interest (b) & 0.17 & 1 & 0.00 & 0.03 & 0.04 & -0.02 & -0.02 & 0.00 & 0.01 \\
\hline Family SES (c) & 0.14 & 0.00 & 1 & 0.17 & 0.12 & 0.16 & 0.20 & 0.32 & 0.30 \\
\hline $\begin{array}{l}\text { Parental literacy cognitive involve- } \\
\text { ment (d) }\end{array}$ & 0.16 & 0.03 & 0.17 & 1 & 0.70 & 0.06 & 0.28 & 0.24 & 0.31 \\
\hline $\begin{array}{l}\text { Parental numeracy cognitive } \\
\text { involvement (e) }\end{array}$ & 0.07 & 0.04 & 0.12 & 0.70 & 1 & 0.06 & 0.22 & 0.17 & 0.25 \\
\hline Pre-school attendance (f) & 0.01 & -0.02 & 0.16 & 0.06 & 0.06 & 1 & 0.04 & 0.05 & 0.05 \\
\hline Parents like reading scale (g) & 0.18 & -0.02 & 0.20 & 0.28 & 0.22 & 0.04 & 1 & 0.46 & 0.33 \\
\hline Number of books at home (h) & 0.17 & 0.00 & 0.32 & 0.24 & 0.17 & 0.05 & 0.46 & 1 & 0.60 \\
\hline $\begin{array}{l}\text { Number of children books at home } \\
\text { (i) }\end{array}$ & 0.22 & 0.01 & 0.30 & 0.31 & 0.25 & 0.05 & 0.33 & 0.60 & 1 \\
\hline
\end{tabular}


Table 3 (continued)

\begin{tabular}{|c|c|c|c|c|c|c|c|c|c|}
\hline & (a) & (b) & (c) & (d) & (e) & (f) & (g) & (h) & (i) \\
\hline \multicolumn{10}{|l|}{ Italy } \\
\hline Student reading interest (a) & 1 & 0.15 & 0.07 & 0.13 & 0.03 & -0.02 & 0.11 & 0.09 & 0.15 \\
\hline Student mathematics interest (b) & 0.15 & 1 & 0.00 & 0.01 & 0.06 & -0.02 & -0.05 & -0.01 & 0.01 \\
\hline Family SES (c) & 0.07 & 0.00 & 1 & 0.16 & 0.09 & 0.11 & 0.26 & 0.42 & 0.30 \\
\hline $\begin{array}{l}\text { Parental literacy cognitive involve- } \\
\text { ment (d) }\end{array}$ & 0.13 & 0.01 & 0.16 & 1 & 0.58 & 0.05 & 0.32 & 0.23 & 0.26 \\
\hline $\begin{array}{l}\text { Parental numeracy cognitive } \\
\text { involvement (e) }\end{array}$ & 0.03 & 0.06 & 0.09 & 0.58 & 1 & 0.07 & 0.19 & 0.14 & 0.18 \\
\hline Pre-school attendance $(f)$ & -0.02 & -0.02 & 0.11 & 0.05 & 0.07 & 1 & 0.05 & 0.10 & 0.10 \\
\hline Parents like reading scale (g) & 0.11 & -0.05 & 0.26 & 0.32 & 0.19 & 0.05 & 1 & 0.46 & 0.35 \\
\hline Number of books at home (h) & 0.09 & -0.01 & 0.42 & 0.23 & 0.14 & 0.10 & 0.46 & 1 & 0.60 \\
\hline $\begin{array}{l}\text { Number of children books at home } \\
\text { (i) }\end{array}$ & 0.15 & 0.01 & 0.30 & 0.26 & 0.18 & 0.10 & 0.35 & 0.60 & 1 \\
\hline \multicolumn{10}{|l|}{ Lithuania } \\
\hline Student reading interest (a) & 1 & 0.13 & 0.06 & 0.12 & 0.03 & 0.01 & 0.10 & 0.12 & 0.18 \\
\hline Student mathematics interest (b) & 0.13 & 1 & 0.02 & 0.00 & 0.08 & 0.01 & -0.01 & 0.00 & -0.01 \\
\hline Family SES (c) & 0.06 & 0.02 & 1 & 0.11 & 0.06 & 0.16 & 0.22 & 0.36 & 0.36 \\
\hline $\begin{array}{l}\text { Parental literacy cognitive involve- } \\
\text { ment (d) }\end{array}$ & 0.12 & 0.00 & 0.11 & 1 & 0.60 & -0.02 & 0.25 & 0.15 & 0.20 \\
\hline $\begin{array}{l}\text { Parental numeracy cognitive } \\
\text { involvement (e) }\end{array}$ & 0.03 & 0.08 & 0.06 & 0.60 & 1 & 0.01 & 0.16 & 0.05 & 0.14 \\
\hline Pre-school attendance $(\mathrm{f})$ & 0.01 & 0.01 & 0.16 & -0.02 & 0.01 & 1 & 0.00 & 0.02 & 0.03 \\
\hline Parents like reading scale (g) & 0.10 & -0.01 & 0.22 & 0.25 & 0.16 & 0.00 & 1 & 0.34 & 0.29 \\
\hline Number of books at home (h) & 0.12 & 0.00 & 0.36 & 0.15 & 0.05 & 0.02 & 0.34 & 1 & 0.61 \\
\hline $\begin{array}{l}\text { Number of children books at home } \\
\text { (i) }\end{array}$ & 0.18 & -0.01 & 0.36 & 0.20 & 0.14 & 0.03 & 0.29 & 0.61 & 1 \\
\hline \multicolumn{10}{|l|}{ Malta } \\
\hline Student reading interest (a) & 1 & 0.22 & 0.06 & 0.15 & 0.09 & 0.04 & 0.09 & 0.07 & 0.13 \\
\hline Student mathematics interest (b) & 0.22 & 1 & 0.03 & 0.05 & 0.06 & 0.03 & 0.00 & 0.03 & 0.03 \\
\hline Family SES (c) & 0.06 & 0.03 & 1 & 0.20 & 0.18 & 0.02 & 0.16 & 0.33 & 0.23 \\
\hline $\begin{array}{l}\text { Parental literacy cognitive involve- } \\
\text { ment (d) }\end{array}$ & 0.15 & 0.05 & 0.20 & 1 & 0.66 & 0.02 & 0.35 & 0.22 & 0.29 \\
\hline $\begin{array}{l}\text { Parental numeracy cognitive } \\
\text { involvement (e) }\end{array}$ & 0.09 & 0.06 & 0.18 & 0.66 & 1 & 0.02 & 0.26 & 0.18 & 0.23 \\
\hline Pre-school attendance (f) & 0.04 & 0.03 & 0.02 & 0.02 & 0.02 & 1 & -0.01 & 0.01 & 0.06 \\
\hline Parents like reading scale (g) & 0.09 & 0.00 & 0.16 & 0.35 & 0.26 & -0.01 & 1 & 0.33 & 0.22 \\
\hline Number of books at home (h) & 0.07 & 0.03 & 0.33 & 0.22 & 0.18 & 0.01 & 0.33 & 1 & 0.50 \\
\hline $\begin{array}{l}\text { Number of children books at home } \\
\text { (i) }\end{array}$ & 0.13 & 0.03 & 0.23 & 0.29 & 0.23 & 0.06 & 0.22 & 0.50 & 1 \\
\hline \multicolumn{10}{|l|}{ Norway } \\
\hline Student reading interest (a) & 1 & 0.19 & 0.08 & 0.12 & 0.01 & -0.01 & 0.14 & 0.12 & 0.11 \\
\hline Student mathematics interest (b) & 0.19 & 1 & 0.04 & -0.01 & 0.04 & 0.01 & -0.03 & -0.02 & -0.01 \\
\hline Family SES (c) & 0.08 & 0.04 & 1 & 0.20 & 0.16 & 0.20 & 0.23 & 0.36 & 0.30 \\
\hline $\begin{array}{l}\text { Parental literacy cognitive involve- } \\
\text { ment (d) }\end{array}$ & 0.12 & -0.01 & 0.20 & 1 & 0.67 & -0.01 & 0.34 & 0.24 & 0.30 \\
\hline $\begin{array}{l}\text { Parental numeracy cognitive } \\
\text { involvement (e) }\end{array}$ & 0.01 & 0.04 & 0.16 & 0.67 & 1 & 0.00 & 0.24 & 0.18 & 0.24 \\
\hline Pre-school attendance (f) & -0.01 & 0.01 & 0.20 & -0.01 & 0.00 & 1 & 0.07 & 0.16 & 0.10 \\
\hline Parents like reading scale (g) & 0.14 & -0.03 & 0.23 & 0.34 & 0.24 & 0.07 & 1 & 0.45 & 0.35 \\
\hline Number of books at home (h) & 0.12 & -0.02 & 0.36 & 0.24 & 0.18 & 0.16 & 0.45 & 1 & 0.63 \\
\hline $\begin{array}{l}\text { Number of children books at home } \\
\text { (i) }\end{array}$ & 0.11 & -0.01 & 0.30 & 0.30 & 0.24 & 0.10 & 0.35 & 0.63 & 1 \\
\hline
\end{tabular}


Table 3 (continued)

\begin{tabular}{|c|c|c|c|c|c|c|c|c|c|}
\hline & (a) & (b) & (c) & (d) & (e) & (f) & (g) & (h) & (i) \\
\hline \multicolumn{10}{|l|}{ Poland } \\
\hline Student reading interest (a) & 1 & 0.21 & 0.12 & 0.18 & 0.08 & -0.01 & 0.14 & 0.13 & 0.15 \\
\hline Student mathematics interest (b) & 0.21 & 1 & 0.03 & 0.02 & 0.05 & -0.03 & -0.01 & 0.01 & 0.00 \\
\hline Family SES (c) & 0.12 & 0.03 & 1 & 0.16 & 0.09 & 0.33 & 0.25 & 0.40 & 0.38 \\
\hline $\begin{array}{l}\text { Parental literacy cognitive involve- } \\
\text { ment (d) }\end{array}$ & 0.18 & 0.02 & 0.16 & 1 & 0.63 & 0.07 & 0.32 & 0.24 & 0.30 \\
\hline $\begin{array}{l}\text { Parental numeracy cognitive } \\
\text { involvement }(\mathrm{e})\end{array}$ & 0.08 & 0.05 & 0.09 & 0.63 & 1 & 0.05 & 0.22 & 0.16 & 0.22 \\
\hline Pre-school attendance (f) & -0.01 & -0.03 & 0.33 & 0.07 & 0.05 & 1 & 0.08 & 0.15 & 0.15 \\
\hline Parents like reading scale (g) & 0.14 & -0.01 & 0.25 & 0.32 & 0.22 & 0.08 & 1 & 0.41 & 0.33 \\
\hline Number of books at home (h) & 0.13 & 0.01 & 0.40 & 0.24 & 0.16 & 0.15 & 0.41 & 1 & 0.63 \\
\hline $\begin{array}{l}\text { Number of children books at home } \\
\text { (i) }\end{array}$ & 0.15 & 0.00 & 0.38 & 0.30 & 0.22 & 0.15 & 0.33 & 0.63 & 1 \\
\hline \multicolumn{10}{|l|}{ Portugal } \\
\hline Student reading interest (a) & 1 & 0.22 & 0.09 & 0.15 & 0.10 & 0.03 & 0.15 & 0.11 & 0.13 \\
\hline Student mathematics interest (b) & 0.22 & 1 & 0.07 & 0.05 & 0.09 & 0.01 & 0.04 & 0.06 & 0.08 \\
\hline Family SES (c) & 0.09 & 0.07 & 1 & 0.21 & 0.18 & 0.18 & 0.22 & 0.44 & 0.39 \\
\hline $\begin{array}{l}\text { Parental literacy cognitive involve- } \\
\text { ment (d) }\end{array}$ & 0.15 & 0.05 & 0.21 & 1 & 0.69 & 0.08 & 0.35 & 0.25 & 0.30 \\
\hline $\begin{array}{l}\text { Parental numeracy cognitive } \\
\text { involvement (e) }\end{array}$ & 0.10 & 0.09 & 0.18 & 0.69 & 1 & 0.07 & 0.26 & 0.21 & 0.26 \\
\hline Pre-school attendance $(f)$ & 0.03 & 0.01 & 0.18 & 0.08 & 0.07 & 1 & 0.07 & 0.09 & 0.10 \\
\hline Parents like reading scale (g) & 0.15 & 0.04 & 0.22 & 0.35 & 0.26 & 0.07 & 1 & 0.36 & 0.29 \\
\hline Number of books at home (h) & 0.11 & 0.06 & 0.44 & 0.25 & 0.21 & 0.09 & 0.36 & 1 & 0.59 \\
\hline $\begin{array}{l}\text { Number of children books at home } \\
\text { (i) }\end{array}$ & 0.13 & 0.08 & 0.39 & 0.30 & 0.26 & 0.10 & 0.29 & 0.59 & 1 \\
\hline \multicolumn{10}{|l|}{ Romania } \\
\hline Student reading interest (a) & 1 & 0.31 & 0.09 & 0.13 & 0.09 & 0.06 & 0.14 & 0.07 & 0.11 \\
\hline Student mathematics interest (b) & 0.31 & 1 & 0.11 & 0.13 & 0.13 & 0.13 & 0.09 & 0.08 & 0.09 \\
\hline Family SES (c) & 0.09 & 0.11 & 1 & 0.27 & 0.28 & 0.25 & 0.30 & 0.43 & 0.37 \\
\hline $\begin{array}{l}\text { Parental literacy cognitive involve- } \\
\text { ment (d) }\end{array}$ & 0.13 & 0.13 & 0.27 & 1 & 0.75 & 0.27 & 0.42 & 0.28 & 0.29 \\
\hline $\begin{array}{l}\text { Parental numeracy cognitive } \\
\text { involvement (e) }\end{array}$ & 0.09 & 0.13 & 0.28 & 0.75 & 1 & 0.28 & 0.35 & 0.26 & 0.28 \\
\hline Pre-school attendance (f) & 0.06 & 0.13 & 0.25 & 0.27 & 0.28 & 1 & 0.14 & 0.14 & 0.14 \\
\hline Parents like reading scale (g) & 0.14 & 0.09 & 0.30 & 0.42 & 0.35 & 0.14 & 1 & 0.42 & 0.37 \\
\hline Number of books at home (h) & 0.07 & 0.08 & 0.43 & 0.28 & 0.26 & 0.14 & 0.42 & 1 & 0.67 \\
\hline $\begin{array}{l}\text { Number of children books at home } \\
\text { (i) }\end{array}$ & 0.11 & 0.09 & 0.37 & 0.29 & 0.28 & 0.14 & 0.37 & 0.67 & 1 \\
\hline \multicolumn{10}{|l|}{ Russian Federation } \\
\hline Student reading interest (a) & 1 & 0.22 & 0.01 & 0.11 & 0.07 & -0.06 & 0.13 & 0.07 & 0.11 \\
\hline Student mathematics interest (b) & 0.22 & 1 & 0.04 & 0.03 & 0.03 & 0.02 & -0.01 & 0.02 & 0.02 \\
\hline Family SES (c) & 0.01 & 0.04 & 1 & 0.13 & 0.13 & 0.14 & 0.16 & 0.22 & 0.23 \\
\hline $\begin{array}{l}\text { Parental literacy cognitive involve- } \\
\text { ment (d) }\end{array}$ & 0.11 & 0.03 & 0.13 & 1 & 0.68 & 0.01 & 0.29 & 0.19 & 0.23 \\
\hline $\begin{array}{l}\text { Parental numeracy cognitive } \\
\text { involvement (e) }\end{array}$ & 0.07 & 0.03 & 0.13 & 0.68 & 1 & 0.04 & 0.23 & 0.18 & 0.24 \\
\hline Pre-school attendance (f) & -0.06 & 0.02 & 0.14 & 0.01 & 0.04 & 1 & -0.01 & 0.02 & 0.01 \\
\hline Parents like reading scale (g) & 0.13 & -0.01 & 0.16 & 0.29 & 0.23 & -0.01 & 1 & 0.34 & 0.27 \\
\hline Number of books at home (h) & 0.07 & 0.02 & 0.22 & 0.19 & 0.18 & 0.02 & 0.34 & 1 & 0.61 \\
\hline $\begin{array}{l}\text { Number of children books at home } \\
\text { (i) }\end{array}$ & 0.11 & 0.02 & 0.23 & 0.23 & 0.24 & 0.01 & 0.27 & 0.61 & 1 \\
\hline
\end{tabular}


Table 3 (continued)

\begin{tabular}{|c|c|c|c|c|c|c|c|c|c|}
\hline & (a) & (b) & (c) & (d) & (e) & (f) & (g) & (h) & (i) \\
\hline \multicolumn{10}{|l|}{ Singapore } \\
\hline Student reading interest (a) & 1 & 0.09 & 0.11 & 0.18 & 0.10 & 0.00 & 0.19 & 0.12 & 0.16 \\
\hline Student mathematics interest (b) & 0.09 & 1 & 0.03 & -0.03 & 0.00 & 0.01 & -0.03 & -0.03 & -0.03 \\
\hline Family SES (c) & 0.11 & 0.03 & 1 & 0.21 & 0.18 & 0.06 & 0.15 & 0.24 & 0.23 \\
\hline $\begin{array}{l}\text { Parental literacy cognitive involve- } \\
\text { ment (d) }\end{array}$ & 0.18 & -0.03 & 0.21 & 1 & 0.74 & 0.05 & 0.37 & 0.23 & 0.24 \\
\hline $\begin{array}{l}\text { Parental numeracy cognitive } \\
\text { involvement (e) }\end{array}$ & 0.10 & 0.00 & 0.18 & 0.74 & 1 & 0.08 & 0.28 & 0.16 & 0.19 \\
\hline Pre-school attendance (f) & 0.00 & 0.01 & 0.06 & 0.05 & 0.08 & 1 & 0.02 & 0.05 & 0.12 \\
\hline Parents like reading scale (g) & 0.19 & -0.03 & 0.15 & 0.37 & 0.28 & 0.02 & 1 & 0.33 & 0.25 \\
\hline Number of books at home (h) & 0.12 & -0.03 & 0.24 & 0.23 & 0.16 & 0.05 & 0.33 & 1 & 0.52 \\
\hline $\begin{array}{l}\text { Number of children books at home } \\
\text { (i) }\end{array}$ & 0.16 & -0.03 & 0.23 & 0.24 & 0.19 & 0.12 & 0.25 & 0.52 & 1 \\
\hline \multicolumn{10}{|l|}{ Slovak Republic } \\
\hline Student reading interest (a) & 1 & 0.19 & 0.08 & 0.12 & 0.07 & 0.01 & 0.18 & 0.12 & 0.16 \\
\hline Student mathematics interest (b) & 0.19 & 1 & 0.06 & 0.04 & 0.07 & 0.03 & 0.00 & 0.04 & 0.06 \\
\hline Family SES (c) & 0.08 & 0.06 & 1 & 0.10 & 0.08 & 0.20 & 0.22 & 0.39 & 0.37 \\
\hline $\begin{array}{l}\text { Parental literacy cognitive involve- } \\
\text { ment (d) }\end{array}$ & 0.12 & 0.04 & 0.10 & 1 & 0.62 & 0.08 & 0.27 & 0.17 & 0.22 \\
\hline $\begin{array}{l}\text { Parental numeracy cognitive } \\
\text { involvement (e) }\end{array}$ & 0.07 & 0.07 & 0.08 & 0.62 & 1 & 0.10 & 0.22 & 0.14 & 0.18 \\
\hline Pre-school attendance (f) & 0.01 & 0.03 & 0.20 & 0.08 & 0.10 & 1 & 0.07 & 0.10 & 0.13 \\
\hline Parents like reading scale (g) & 0.18 & 0.00 & 0.22 & 0.27 & 0.22 & 0.07 & 1 & 0.38 & 0.31 \\
\hline Number of books at home (h) & 0.12 & 0.04 & 0.39 & 0.17 & 0.14 & 0.10 & 0.38 & 1 & 0.63 \\
\hline $\begin{array}{l}\text { Number of children books at home } \\
\text { (i) }\end{array}$ & 0.16 & 0.06 & 0.37 & 0.22 & 0.18 & 0.13 & 0.31 & 0.63 & 1 \\
\hline \multicolumn{10}{|l|}{ Slovenia } \\
\hline Student reading interest (a) & 1 & 0.22 & 0.07 & 0.14 & 0.05 & 0.01 & 0.15 & 0.09 & 0.12 \\
\hline Student mathematics interest (b) & 0.22 & 1 & 0.00 & 0.06 & 0.07 & 0.00 & -0.01 & -0.02 & -0.01 \\
\hline Family SES (c) & 0.07 & 0.00 & 1 & 0.19 & 0.13 & 0.15 & 0.25 & 0.37 & 0.39 \\
\hline $\begin{array}{l}\text { Parental literacy cognitive involve- } \\
\text { ment (d) }\end{array}$ & 0.14 & 0.06 & 0.19 & 1 & 0.67 & 0.03 & 0.32 & 0.21 & 0.26 \\
\hline $\begin{array}{l}\text { Parental numeracy cognitive } \\
\text { involvement (e) }\end{array}$ & 0.05 & 0.07 & 0.13 & 0.67 & 1 & 0.05 & 0.25 & 0.17 & 0.24 \\
\hline Pre-school attendance (f) & 0.01 & 0.00 & 0.15 & 0.03 & 0.05 & 1 & 0.05 & 0.05 & 0.10 \\
\hline Parents like reading scale (g) & 0.15 & -0.01 & 0.25 & 0.32 & 0.25 & 0.05 & 1 & 0.37 & 0.35 \\
\hline Number of books at home (h) & 0.09 & -0.02 & 0.37 & 0.21 & 0.17 & 0.05 & 0.37 & 1 & 0.63 \\
\hline $\begin{array}{l}\text { Number of children books at home } \\
\text { (i) }\end{array}$ & 0.12 & -0.01 & 0.39 & 0.26 & 0.24 & 0.10 & 0.35 & 0.63 & 1 \\
\hline \multicolumn{10}{|l|}{ Spain } \\
\hline Student reading interest (a) & 1 & 0.20 & 0.11 & 0.12 & 0.05 & 0.00 & 0.12 & 0.11 & 0.12 \\
\hline Student mathematics interest (b) & 0.20 & 1 & 0.02 & 0.02 & 0.03 & 0.02 & 0.01 & 0.01 & 0.01 \\
\hline Family SES (c) & 0.11 & 0.02 & 1 & 0.17 & 0.13 & 0.11 & 0.23 & 0.41 & 0.36 \\
\hline $\begin{array}{l}\text { Parental literacy cognitive involve- } \\
\text { ment (d) }\end{array}$ & 0.12 & 0.02 & 0.17 & 1 & 0.66 & 0.07 & 0.37 & 0.25 & 0.27 \\
\hline $\begin{array}{l}\text { Parental numeracy cognitive } \\
\text { involvement (e) }\end{array}$ & 0.05 & 0.03 & 0.13 & 0.66 & 1 & 0.07 & 0.24 & 0.18 & 0.23 \\
\hline Pre-school attendance (f) & 0.00 & 0.02 & 0.11 & 0.07 & 0.07 & 1 & 0.07 & 0.11 & 0.09 \\
\hline Parents like reading scale (g) & 0.12 & 0.01 & 0.23 & 0.37 & 0.24 & 0.07 & 1 & 0.45 & 0.33 \\
\hline Number of books at home (h) & 0.11 & 0.01 & 0.41 & 0.25 & 0.18 & 0.11 & 0.45 & 1 & 0.61 \\
\hline $\begin{array}{l}\text { Number of children books at home } \\
\text { (i) }\end{array}$ & 0.12 & 0.01 & 0.36 & 0.27 & 0.23 & 0.09 & 0.33 & 0.61 & 1 \\
\hline
\end{tabular}


Table 3 (continued)

\begin{tabular}{|c|c|c|c|c|c|c|c|c|c|}
\hline & (a) & (b) & (c) & (d) & (e) & (f) & (g) & (h) & (i) \\
\hline \multicolumn{10}{|l|}{ Sweden } \\
\hline Student reading interest (a) & 1 & 0.18 & 0.12 & 0.21 & 0.10 & 0.03 & 0.20 & 0.13 & 0.17 \\
\hline Student mathematics interest (b) & 0.18 & 1 & 0.02 & 0.04 & 0.07 & -0.02 & 0.01 & -0.02 & -0.01 \\
\hline Family SES (c) & 0.12 & 0.02 & 1 & 0.22 & 0.14 & 0.19 & 0.30 & 0.37 & 0.30 \\
\hline $\begin{array}{l}\text { Parental literacy cognitive involve- } \\
\text { ment (d) }\end{array}$ & 0.21 & 0.04 & 0.22 & 1 & 0.71 & 0.06 & 0.38 & 0.25 & 0.27 \\
\hline $\begin{array}{l}\text { Parental numeracy cognitive } \\
\text { involvement (e) }\end{array}$ & 0.10 & 0.07 & 0.14 & 0.71 & 1 & 0.04 & 0.29 & 0.16 & 0.18 \\
\hline Pre-school attendance $(f)$ & 0.03 & -0.02 & 0.19 & 0.06 & 0.04 & 1 & 0.09 & 0.13 & 0.14 \\
\hline Parents like reading scale (g) & 0.20 & 0.01 & 0.30 & 0.38 & 0.29 & 0.09 & 1 & 0.47 & 0.33 \\
\hline Number of books at home (h) & 0.13 & -0.02 & 0.37 & 0.25 & 0.16 & 0.13 & 0.47 & 1 & 0.60 \\
\hline $\begin{array}{l}\text { Number of children books at home } \\
\text { (i) }\end{array}$ & 0.17 & -0.01 & 0.30 & 0.27 & 0.18 & 0.14 & 0.33 & 0.60 & 1 \\
\hline \multicolumn{10}{|l|}{ United Arab Emirates } \\
\hline Student reading interest (a) & 1 & 0.27 & 0.09 & 0.13 & 0.08 & 0.01 & 0.15 & 0.09 & 0.13 \\
\hline Student mathematics interest (b) & 0.27 & 1 & 0.08 & 0.06 & 0.07 & 0.02 & 0.03 & 0.03 & 0.04 \\
\hline Family SES (c) & 0.09 & 0.08 & 1 & 0.13 & 0.13 & 0.05 & 0.14 & 0.22 & 0.16 \\
\hline $\begin{array}{l}\text { Parental literacy cognitive involve- } \\
\text { ment (d) }\end{array}$ & 0.13 & 0.06 & 0.13 & 1 & 0.65 & 0.08 & 0.31 & 0.19 & 0.24 \\
\hline $\begin{array}{l}\text { Parental numeracy cognitive } \\
\text { involvement (e) }\end{array}$ & 0.08 & 0.07 & 0.13 & 0.65 & 1 & 0.07 & 0.23 & 0.14 & 0.20 \\
\hline Pre-school attendance (f) & 0.01 & 0.02 & 0.05 & 0.08 & 0.07 & 1 & 0.03 & 0.06 & 0.05 \\
\hline Parents like reading scale (g) & 0.15 & 0.03 & 0.14 & 0.31 & 0.23 & 0.03 & 1 & 0.34 & 0.26 \\
\hline Number of books at home (h) & 0.09 & 0.03 & 0.22 & 0.19 & 0.14 & 0.06 & 0.34 & 1 & 0.55 \\
\hline $\begin{array}{l}\text { Number of children books at home } \\
\text { (i) }\end{array}$ & 0.13 & 0.04 & 0.16 & 0.24 & 0.20 & 0.05 & 0.26 & 0.55 & 1 \\
\hline \multicolumn{10}{|l|}{ Abu Dhabi } \\
\hline Student reading interest (a) & 1 & 0.29 & 0.10 & 0.14 & 0.09 & -0.01 & 0.15 & 0.07 & 0.11 \\
\hline Student mathematics interest (b) & 0.29 & 1 & 0.09 & 0.09 & 0.09 & 0.00 & 0.04 & 0.02 & 0.04 \\
\hline Family SES (c) & 0.10 & 0.09 & 1 & 0.15 & 0.13 & 0.06 & 0.17 & 0.22 & 0.16 \\
\hline $\begin{array}{l}\text { Parental literacy cognitive involve- } \\
\text { ment (d) }\end{array}$ & 0.14 & 0.09 & 0.15 & 1 & 0.64 & 0.10 & 0.31 & 0.17 & 0.21 \\
\hline $\begin{array}{l}\text { Parental numeracy cognitive } \\
\text { involvement (e) }\end{array}$ & 0.09 & 0.09 & 0.13 & 0.64 & 1 & 0.09 & 0.25 & 0.13 & 0.19 \\
\hline Pre-school attendance (f) & -0.01 & 0.00 & 0.06 & 0.10 & 0.09 & 1 & 0.03 & 0.08 & 0.06 \\
\hline Parents like reading scale (g) & 0.15 & 0.04 & 0.17 & 0.31 & 0.25 & 0.03 & 1 & 0.34 & 0.25 \\
\hline Number of books at home (h) & 0.07 & 0.02 & 0.22 & 0.17 & 0.13 & 0.08 & 0.34 & 1 & 0.53 \\
\hline $\begin{array}{l}\text { Number of children books at home } \\
\text { (i) }\end{array}$ & 0.11 & 0.04 & 0.16 & 0.21 & 0.19 & 0.06 & 0.25 & 0.53 & 1 \\
\hline \multicolumn{10}{|l|}{ Dubai } \\
\hline Student reading interest (a) & 1 & 0.24 & 0.09 & 0.14 & 0.08 & 0.04 & 0.17 & 0.12 & 0.17 \\
\hline Student mathematics interest (b) & 0.24 & 1 & 0.06 & 0.05 & 0.06 & 0.03 & 0.03 & 0.04 & 0.04 \\
\hline Family SES (c) & 0.09 & 0.06 & 1 & 0.10 & 0.12 & 0.05 & 0.13 & 0.21 & 0.15 \\
\hline $\begin{array}{l}\text { Parental literacy cognitive involve- } \\
\text { ment (d) }\end{array}$ & 0.14 & 0.05 & 0.10 & 1 & 0.66 & 0.05 & 0.32 & 0.21 & 0.27 \\
\hline $\begin{array}{l}\text { Parental numeracy cognitive } \\
\text { involvement (e) }\end{array}$ & 0.08 & 0.06 & 0.12 & 0.66 & 1 & 0.04 & 0.23 & 0.15 & 0.22 \\
\hline Pre-school attendance (f) & 0.04 & 0.03 & 0.05 & 0.05 & 0.04 & 1 & 0.02 & 0.04 & 0.03 \\
\hline Parents like reading scale (g) & 0.17 & 0.03 & 0.13 & 0.32 & 0.23 & 0.02 & 1 & 0.35 & 0.28 \\
\hline Number of books at home (h) & 0.12 & 0.04 & 0.21 & 0.21 & 0.15 & 0.04 & 0.35 & 1 & 0.57 \\
\hline $\begin{array}{l}\text { Number of children books at home } \\
\text { (i) }\end{array}$ & 0.17 & 0.04 & 0.15 & 0.27 & 0.22 & 0.03 & 0.28 & 0.57 & 1 \\
\hline
\end{tabular}




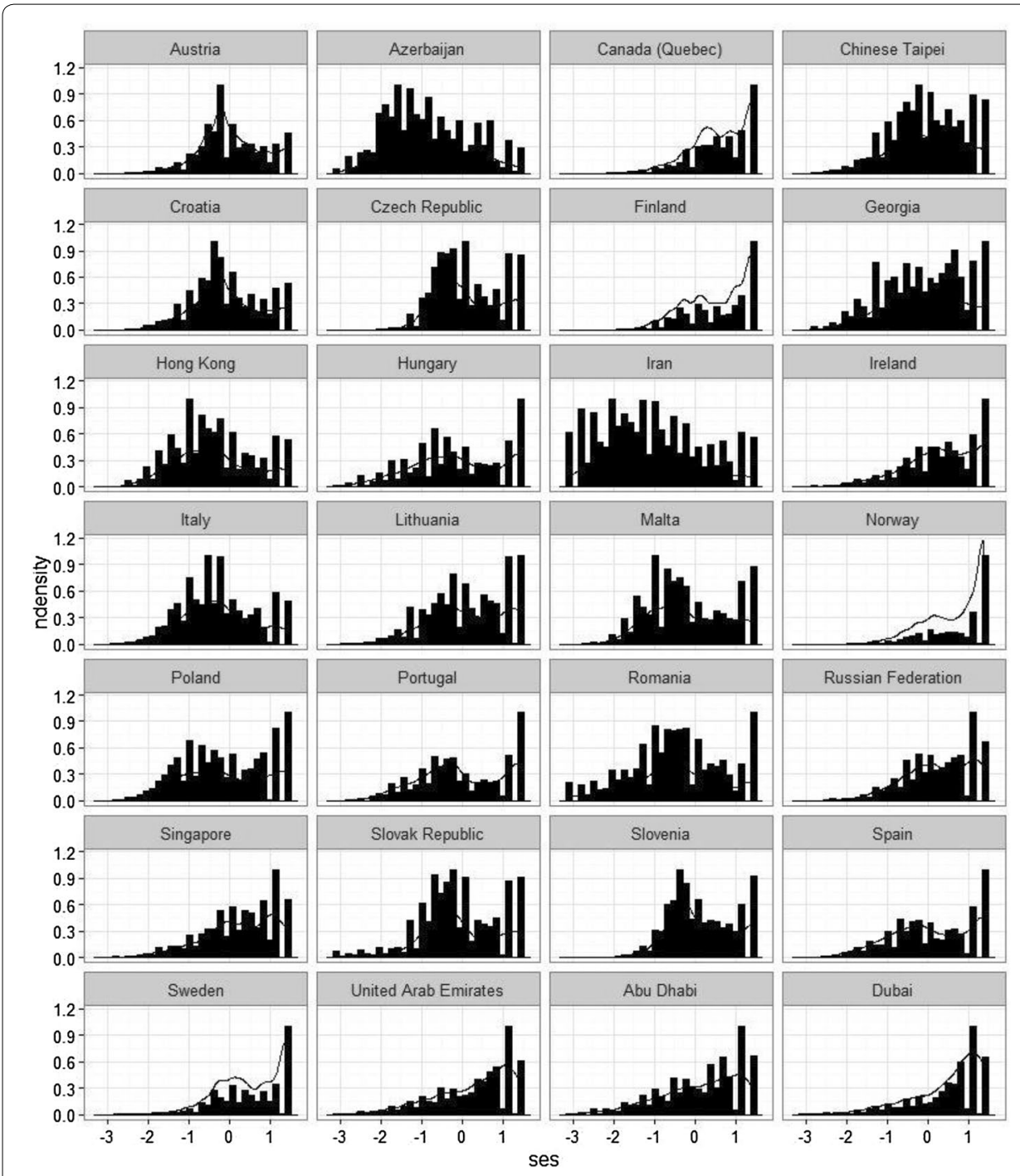

Fig. 5 Distribution of family SES by education system

Appendix B: Mediation results and sensitivity analysis

See Tables 4, 5 and Figs. 6, 7. 


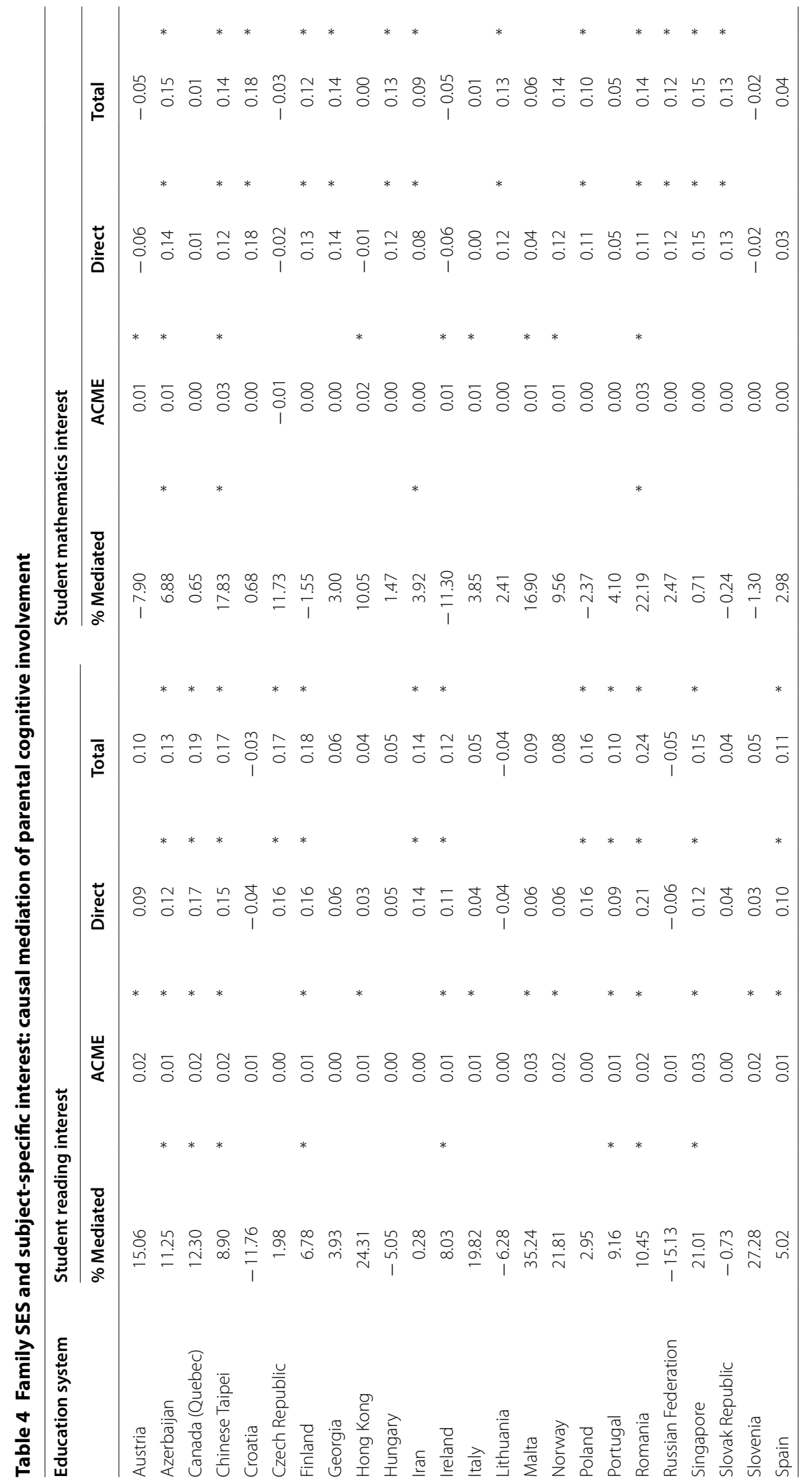




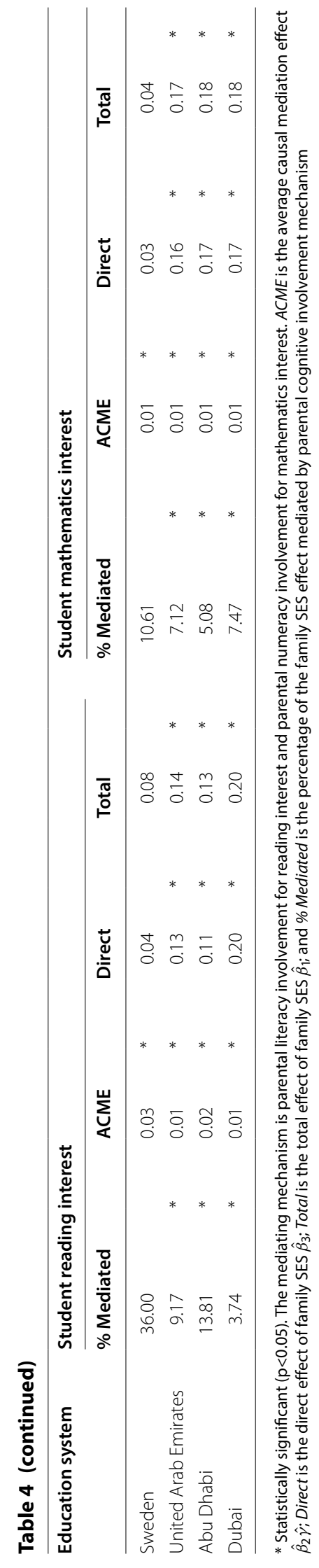


Table 5 Direct association with parental cognitive involvement: unstandardised regression coefficients

\begin{tabular}{|c|c|c|c|c|}
\hline \multirow{2}{*}{$\begin{array}{l}\text { Education system } \\
\text { Austria }\end{array}$} & \multicolumn{2}{|c|}{ (1) Student reading interest } & \multicolumn{2}{|c|}{$\begin{array}{l}\text { (2) Student } \\
\text { mathematics interest }\end{array}$} \\
\hline & 0.14 & * & 0.08 & * \\
\hline Azerbaijan & 0.08 & * & 0.04 & * \\
\hline Canada (Quebec) & 0.10 & * & 0.08 & * \\
\hline Chinese Taipei & 0.09 & * & 0.07 & * \\
\hline Croatia & 0.13 & * & 0.07 & * \\
\hline Czech Republic & 0.06 & * & 0.07 & * \\
\hline Finland & 0.17 & * & 0.08 & * \\
\hline Georgia & 0.06 & * & 0.02 & \\
\hline Hong Kong & 0.09 & * & 0.11 & * \\
\hline Hungary & 0.12 & * & 0.10 & * \\
\hline Iran & 0.04 & * & 0.05 & * \\
\hline Ireland & 0.07 & * & 0.08 & * \\
\hline Italy & 0.10 & * & 0.07 & * \\
\hline Lithuania & 0.08 & * & 0.11 & * \\
\hline Malta & 0.14 & * & 0.06 & * \\
\hline Norway & 0.07 & * & 0.05 & \\
\hline Poland & 0.17 & * & 0.07 & * \\
\hline Portugal & 0.10 & * & 0.04 & \\
\hline Romania & 0.07 & * & 0.08 & * \\
\hline Russian Federation & 0.06 & * & 0.02 & \\
\hline Singapore & 0.09 & * & 0.00 & \\
\hline Slovak Republic & 0.10 & * & 0.08 & * \\
\hline Slovenia & 0.11 & * & 0.09 & * \\
\hline Spain & 0.08 & * & 0.06 & * \\
\hline Sweden & 0.13 & * & 0.08 & * \\
\hline United Arab Emirates & 0.08 & * & 0.06 & * \\
\hline Abu Dhabi & 0.10 & * & 0.07 & * \\
\hline Dubai & 0.07 & * & 0.07 & * \\
\hline
\end{tabular}

(1) Regression of student interest in reading on SES, parental reading involvement and confounders. (2) Regression of student interest in mathematics on SES, parental numeracy involvement and confounders. Parental involvement coefficients are reported

* Statistically significant $(p<0.05)$

(See figure on next page.)

Fig. 6 Sensitivity analysis for the mediating effect of parental literacy involvement in the family SES and reading interest relationship 

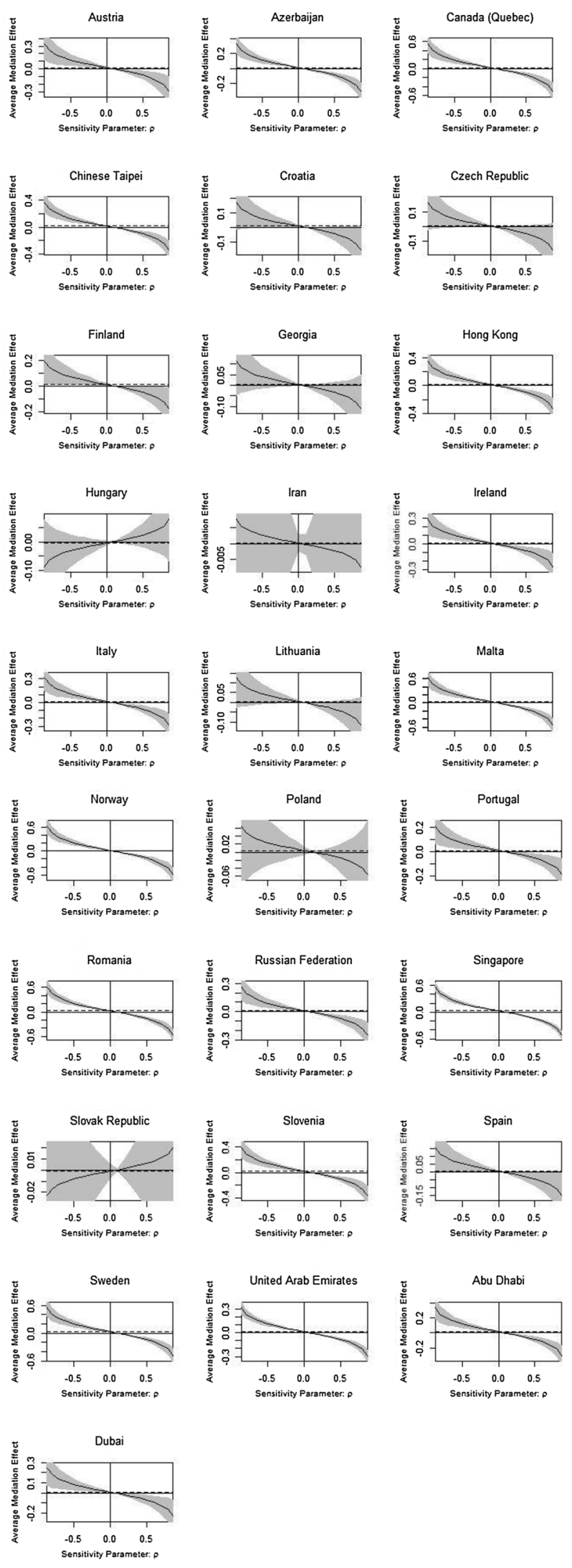

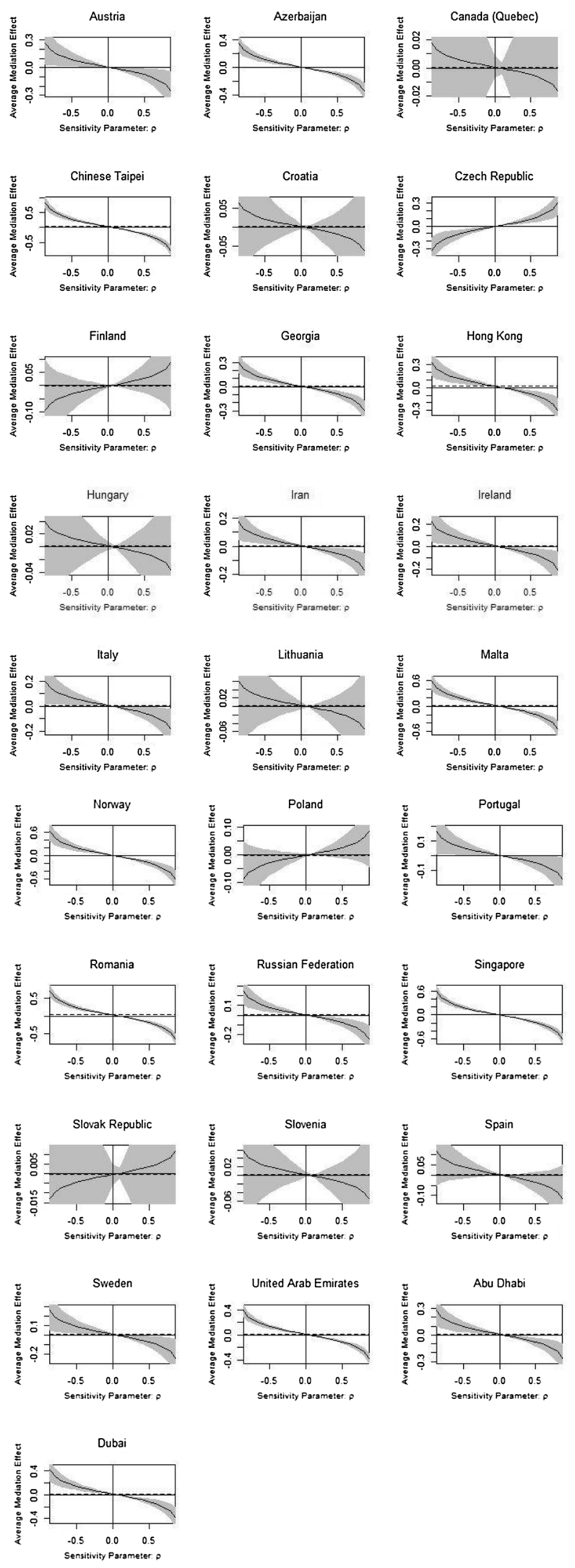
(See figure on previous page.)

Fig. 7 Sensitivity analysis for the mediating effect of parental numeracy involvement in the family SES and mathematics interest relationship

\section{Publisher's Note}

Springer Nature remains neutral with regard to jurisdictional claims in published maps and institutional affiliations.

Received: 24 March 2018 Accepted: 26 October 2018

Published online: 01 November 2018

\section{References}

Appleton, J. J., Christenson, S. L., Kim, D., \& Reschly, A. L. (2006). Measuring cognitive and psychological engagement: Validation of the student engagement instrument. Journal of School Psychology, 44(5), 427-445.

Artelt, C. (2005). Cross-cultural approaches to measuring motivation. Educational Assessment, 10(3), 231-255. https://doi. org/10.1207/s15326977ea1003_5.

Baker, L., Serpell, R., \& Sonnenschein, S. (1995). Opportunities for literacy learning in the homes of urban preschoolers. In L. Morrow (Ed.), Family literacy: Connections in schools and communities (pp. 236-252). Newark: International Reading Association.

Bandura, A. (1989). Human agency in social cognitive theory. American Psychologist, 44(9), 1175-1184.

Baron, R., \& Kenny, D. (1986). The moderator-mediator variable distinction in social psychological research: Conceptual, strategic and statistical considerations. Journal of Personality and Social Psychology, 51, 1173-1182.

Bempechat, J., \& Shernoff, D. (2012). Parental influences on achievement motivation and student engagement. In S. Christenson, A. Reschly, \& C. Wylie (Eds.), Handbook of research on student engagement (pp. 315-342). New York: Springer.

Birch, S. H., \& Ladd, G. W. (1998). Children's interpersonal behaviors and the teacher-child relationship. Developmental Psychology, 34, 934-946.

Buckley, J. (2009). Cross-National Response Styles in International Educational Assessments: Evidence from PISA 2006. https:// edsurveys.rti.org/PISA/documents/Buckley_PISAresponsestyle.pdf.

Caro, D. H. (2011). Parent-child communication and academic performance: Associations at the within- and betweencountry level. Journal for Educational Research Online, 3(2), 15-37.

Caro, D. H. (2015). Causal mediation in educational research: An illustration using international assessment data. Journal of Research on Educational Effectiveness, 8(4), 577-597.

Caro, D. H., \& Cortés, D. (2012). Measuring family socioeconomic status: An illustration using data from PIRLS 2006. IERI Monograph Series: Issues and Methodologies in Large-Scale Assessments, 5, 9-33.

Caro, D. H., \& Lenkeit, J. (2012). An analytical approach to study educational inequalities: 10 hypothesis tests in PIRLS 2006. International Journal of Research and Method in Education, 35(1), 3-30.

Caro, D. H., Lenkeit, J., \& Kyriakides, L. (2016). Teaching strategies and differential effectiveness across learning contexts: Evidence from PISA 2012. Studies in Educational Evaluation, 49, 30-41.

Caro, D. H., \& Mirazchiyski, P. (2012). Socioeconomic gradients in eastern european countries: Evidence from PIRLS 2006. European Educational Research Journal, 11(1), 96-110.

Caro, D. H., Sandoval-Hernandez, A., \& Lüdtke, O. (2014). Cultural, social and economic capital constructs in international assessments: An evaluation using exploratory structural equation modeling. School Effectiveness and School Improvement, 25(3), 433-450.

Chirkov, V. I. \& Ryan, R. M. (2001). Parent and teacher autonomy-support in Russian and US adolescents common effects on well-being and academic motivation. Journal of Cross-Cultural Psychology, 32(5), 618-635.

Chirkov, V. I., Ryan, R. M., \& Sheldon, K. M. (2011). Human autonomy in cross-cultural contexts: Perspectives on the psychology of agency, freedom, and well-being. Dordrecht: Springer.

Chiu, M. M., \& Chow, B. W. Y. (2010). Culture, motivation, and reading achievement: High school students in 41 countries. Learning and Individual Differences, 20(6), 579-592. https://doi.org/10.1016/j.lindif.2010.03.007.

Creemers, B. P. M., \& Kyriakides, L. (2008). The dynamics of educational effectiveness a contribution to policy, practice and theory in contemporary schools. London: Routledge.

Deci, E. L. (1992). On the nature and function of motivational theories. Psychological Science, 3, 167-171.

Deci, E. L., \& Ryan, R. M. (2002). Overview of self-determination theory: An organismic dialectical perspective. In E. L. Deci \& R. M. Ryan (Eds.), Handbook of self-determination research (pp. 3-33). Rochester: University of Rochester Press.

Deci, E. L., \& Ryan, R. M. (2012). Motivation, personality, and development within embedded social contexts: An overview of self-determination theory. In R. C. Ryan (Ed.), The Oxford handbook of motivation (pp. 85-107). New York: Oxford University Press.

Eccles, J. S. (2005). Subjective task value and the Eccles et al. model of achievement-related choices. In A. J. Elliot \& C. S. Dweck (Eds.), Handbook of competence and motivation (pp. 105-121). New York: The Guilford Press.

Eccles, J. S., Wigfield, A., \& Schiefele, U. (1998). Motivation to succeed. In W. Damon \& N. Eisenberg (Eds.), Handbook of child psychology (5th ed., Vol. 3, pp. 1017-1095). New York: John Wiley.

Evans, M. A., Shaw, D., \& Bell, M. (2000). Home literacy activities and their influence on early literacy skills. Canadian Journal of Experimental Psychology, 54, 65-75.

Fan, W., \& Williams, C. M. (2010). The effects of parental involvement on students' academic self-efficacy, engagement and intrinsic motivation. Educational Psychology, 30(1), 53-74. 
Frenzel, A. C., Goetz, T., Pekrun, R., \& Watt, H. M. G. (2010). Development of mathematics interest in adolescence: Influences of gender, family, and school context. Journal of Research on Adolescence, 20(2), 507-537.

Ganzeboom, H. B. G., de Graaf, P. M., \& Treiman, D. J. (1992). A standard international socio-economic index of occupational status. Social Science Research, 21, 1-56.

Gottfried, A. E., Fleming, J. S., \& Gottfried, A. W. (1998). Role of cognitively stimulating home environment in children's academic intrinsic motivation: A longitudinal study. Child Development, 69(5), 1448-1460.

Gottfried, A. E., Marcoulides, G. A., Gottfried, A. W., Oliver, P. H., \& Guerin, D. W. (2007). Multivariate latent change modeling of developmental decline in academic intrinsic math motivation and achievement: Childhood through adolescence. International Journal of Behavioral Development, 31, 317-327.

Gottfried, A. W., Schlackman, J., Gottfried, A. E., \& Boutin-Martinez, A. S. (2015). Parental provision of early literacy environment as related to reading and educational outcomes across the academic lifespan. Parenting, 15(1), 24-38. https ://doi.org/10.1080/15295192.2015.992736.

Greene, B. A., Miller, R. B., Crowson, H. M., Duke, B. L., \& Akey, K. L. (2004). Predicting high school students' cognitive engagement and achievement: Contributions of classroom perceptions and motivation. Contemporary Educational Psychology, 29, 462-482.

Grolnick, W. S., Friendly, R., \& Bellas, V. (2009). Parenting and children's motivation at school. In K. Wentzel \& A. Wigfield (Eds.), Handbook of motivation at school. Lawrence Erlbaum and Associates: Mahwah, NJ.

Grolnick, W. S., \& Slowiaczek, M. L. (1994). Parents' involvement in children's schooling: A multidimensional conceptualization and motivational model. Child Development, 65, 237-252.

Gustafsson, J., Hansen, K., \& Rosén, M. (2013). Effects of home background on student achievement in reading, mathematics and science at the fourth grade. In M. O. Martin \& I. V. S. Mullis (Eds.), TIMSS and PIRLS 2011: Relationships among reading, mathematics, and science achievement at the fourth grade - Implications for early learning. Chestnut Hill: TIMSS PIRLS International Study Center, Boston College.

Guthrie, J.T., Hoa, A. L. W., Wigfield, A., Tonks, S. M., Humenick, N. M., \& Littles, E. (2007). Reading motivation and reading comprehension growth in the later elementary years. Contemporary Educational Psychology, 32(3), 282-313. https ://doi.org/10.1016/j.cedpsych.2006.05.004.

Gutman, L. M., \& Sulzby, E. (2000). The role of autonomy-support versus control in the emergent writing behaviors of African American kindergarten children. Reading Research and Instruction, 39, 170-184.

Hardre, P., \& Reeve, J. (2003). A motivational model of rural students' intentions to persist in, versus drop out of, high school. Journal of Educational Psychology, 95, 347-356.

Harzing, A. W. K. (2006). Response styles in cross-national survey research: A 26-country study. International Journal of Cross Cultural Management, 6, 243-266.

Holland, P. W. (1986). Statistics and Causal Inference. Journal of the American Statistical Association, 81, 945-960.

Imai, K., Keele, L., \& Tingley, D. (2010a). A general approach to causal mediation analysis. Psychological Methods, 15(4), 309-334.

Imai, K., Keele, L., Tingley, D., \& Yamamoto, T. (2010b). Causal mediation analysis using R. In H. D. Vinod (Ed.), Advances in social science research using R (pp. 129-154). New York: Lecture Notes in Statistics. Springerverlag.

Jang, H., Reeve, J., \& Deci, E. L. (2007). Engaging students in learning activities: It's not autonomy support or structure, but autonomy support and structure. Journal of Educational Psychology, 102(3), 588-600.

Jimerson, S. J., Campos, E., \& Greif, J. L. (2003). Towards an understanding of definitions and measures of school engagement and related terms. California School Psychologist, 8, 7-27.

Kirsch, I., de Jong, J., Lafontaine, D., McQueen, J., Mendelovits, J., \& Monseur, C. (2003). Reading for change: Performance and engagement across countries results from PISA 2000. Paris: Organisation for Economic Co-operation and Development.

Kraemer, H. C., Stice, E., Kazdin, A., Offord, D., \& Kupfer, D. (2001). How do risk factors work together? Mediators, moderators, and independent, overlapping, and proxy risk factors. The American Journal of Psychiatry, 158(6), 848-856.

Kraft, M. A., \& Dougherty, Shaun M. (2013). The effect of teacher-family communication on student engagement: Evidence from a randomized field experiment. Journal of Research on Educational Effectiveness, 6(3), 199-222.

Kriegbaum, K., \& Spinath, B. (2016). Explaining social disparities in mathematical achievement: The role of motivation. European Journal of Personality, 30, 45-63.

LeFevre, J. A., Skwarchuk, S. L., Smith-Chant, B. L., Fast, L., Kamawar, D., \& Bisanz, J. (2009). Home numeracy experiences and children'smath performance in the early school years. Canadian Journal of Behavioural Science, 41, 55-66. https ://doi.org/10.1037/a0014532.

Little, M., \& Kobak, R. (2003). Emotional security with teachers and children's stress reactivity: A comparison of specialeducation and regular-education classrooms. Journal of Clinical Child and Adolescent Psychology, 32, 127-138.

Luschei, T. F., \& Chudgar, A. (2011). Teachers, student achievement and national income: A cross-national examination of relationships and interactions. Prospects, 41(4), 507-533.

Mackinnon, D. P. (2008). Introduction to statistical mediation analysis. Mahwah: Erlbaum.

Marbell, K., \& Grolnick, W. S. (2013). Correlates of parental control and autonomy support in an interdependent culture: A look at Ghana. Motivation and Emotion, 37(1), 79-92.

Martin, A. (2006). The relationship between teachers' perceptions of student motivation and engagement and teachers' enjoyment of and confidence in teaching. Asia-Pacific Journal of Teacher Education, 34(1), 73-93.

Martin, M. O., \& Mullis, I. V. S. (Eds.). (2013). TIMSS and PIRLS 2011: Relationships among reading, mathematics, and science achievement at the fourth grade-implications for early learning. Chestnut Hill, ubuntu use microsoft wordMA: TIMSS \& PIRLS International Study Center, Boston College.

McElvany, N., Kortenbruck, M., \& Becker, M. (2008). Lesekompetenz und Lesemotivation: Entwicklung und Mediation des Zusammenhangs durch Leseverhalten [Reading competence and reading motivation: Their development and the mediation of the relationship by reading behavior]. Zeitschrift für Pädagogische Psychologie, 22, 207-219.

McLanahan, S. (2004). Diverging destinies: How children are faring under the second demographic transition. Demography, 41(4), 607-627. 
Meece, J. L., Anderman, E. M., \& Anderman, L. H. (2006). Classroom goal structures, student motivation, and academic achievement. Annual Review of Psychology, 57, 487-504.

Midgley, C., Feldlaufer, H., \& Eccles, J. (1989). Student/teacher relations and attitudes toward mathematics before and after the transition to junior high school. Child Development, 60, 981-992.

Mottet, T. P., Frymier, A. B., \& Beebe, S. A. (2006). Theorizing about instructional communication. In T. P. Mottet, V. P. Richmond, \& J. C. McCroskey (Eds.), Handbook of instructional communication (p. 255282). Boston: Pearson.

Mullis, I. V. S., Martin, M. O., Foy, P., \& Arora, A. (2012a). TIMSS 2011 international results in mathematics. Chestnut Hill: TIMSS \& PIRLS International Study Centre, Lynch School of Education, Boston College International Association for the Evaluation of Educational Achievement (IEA), IEA Secretariat.

Mullis, I. V. S., Martin, M. O., Foy, P., \& Drucker, K. T. (2012b). PIRLS 2011 international results in reading. Chestnut Hill: TIMSS \& PIRLS International Study Centre, Lynch School of Education, Boston College International Association for the Evaluation of Educational Achievement (IEA), IEA Secretariat.

Neuman, S. B., Kaefer, P. T., Pinkham, A., \& Strouse, G. (2014). Can babies learn to read? A randomized trial of baby media. Journal of Educational Psychology, 106, 815-830. https://doi.org/10.1037/a0035937.

Niklas, F., \& Schneider, W. (2013). Home literacy environment and the beginning of reading and spelling. Contemporary Educational Psychology, 38, 40-50.

OECD. (2013a). PISA 2012 results: Excellence through equity: Giving every student the chance to succeed (Vol. II). PISA: OECD Publishing.

OECD. (2013b). PISA 2012 results: Ready to learn: Students' engagement, drive and self-beliefs (Vol. III). PISA: OECD Publishing.

Park, H. (2008a). Home literacy environments and children's reading performance: A comparative study of 25 countries. Educational Research and Evaluation, 14(6), 489-505.

Park, H. (2008b). The varied educational effects of parent-child communication: A comparative study of fourteen countries. Comparative Education Review, 52(2), 219-243.

Parker, F. L., Boak, A. Y., Griffin, K. W., Ripple, C., \& Peay, L. (1999). Parent-child relationship, home learning environment, and school readiness. School Psychology Review, 28, 413-425.

Pianta, R. C., Hamre, B. K., \& Allen, J. P. (2012). Teacher-student relationships and engagement: Conceptualizing, measuring, and improving the capacity of classroom interactions (pp. 365-386)., Handbook of research on student engagement Berlin: Springer.

Pintrich, P. R. (2003). A motivational science perspective of the role of student motivation in learning and teaching contexts. Journal of Educational Psychology, 95, 667-686.

Pintrich, P. R., \& De Groot, E. V. (1990). Motivational and self-regulated learning components of classroom academic performance. Journal of Educational Psychology, 82(1), 33-40.

Pintrich, P. R. \& Schunk, D. H. (2003). Motivation in education: Theory, research, and application (2nd ed.). Englewood Cliff s: Merrill-Prentice Hall.

Pokropek, A., Borgonovi, F., \& Jakubowski, M. (2015). Socio-economic disparities in academic achievement: A comparative analysis of mechanisms and pathways. Learning and Individual Differences, 42, 10-18.

Strietholt, R. Borgna, C. (2016). How is inequality measured in international studies on educational achievement? Paper presented at the CIDER conference, Berlin, January 2016.

Raftery-Helmer, J. N., \& Grolnick, W. S. (2015). Children's coping with academic failure: Relations with contextual and motivational resources supporting competence. Journal of Early Adolescence, 2, 1-25. https://doi.org/10.1177/02724 31615594459

Raikes, H., Pan, B. A., Luze, G., Tamis-LeMonda, C. S., Brooks-Gunn, J., Constantine, J., et al. (2006). Mother-child bookreading in low-income families: Correlates and outcomes during the first three years of life. Child Development, 77(4), 924-953.

Reeve, J. (2005). Understanding motivation and emotion (4th ed.). Hoboken: Wiley.

Retelsdorf, J., Köller, O., \& Möller, J. (2011). On the effects of motivation on reading performance growth in secondary school. Learning and Instruction, 21, 550-559.

Rubin, D. B. (1974). Estimating causal effects of treatments in randomized and non-randomized studies. Journal of Educational Psychology, 66, 688-701.

Schaffner, E., Philipp, M., \& Schiefele, U. (2016). Reciprocal effects between intrinsic reading motivation and reading competence? A cross-lagged panel model for academic track and nonacademic track students. Journal of Research in Reading, 39(1), 19-36.

Schaffner, E., Schiefele, U., \& Ulferts, H. (2013). Reading amount as a mediator of the effects of intrinsic and extrinsic reading motivation on reading comprehension. Reading Research Quarterly, 48, 369-385. https://doi.org/10.1002/ rra.52.

Schiefele, U. (1996). Topic interest, text representation, and quality of experience. Contemporary Educational Psychology, 21, 3-18.

Schiefele, U. (2004). Förderung von Interessen [Facilitation of interest]. In G. W. Lauth, M. Grünke, \& J. C. Brunstein (Eds.), Interventionen bei Lernstörungen (pp. 134-144). Göttingen: Hogrefe.

Schiefele, U. (2009). Situational and individual interest. In K. R. Wentzel \& A. Wigfield (Eds.), Handbook of motivation at school (pp. 197-222). New York: Routledge.

Schiefele, U., Krapp, A., \& Winteler, A. (1992). Interest as a predictor of academic achievement: A meta-analysis of research. In K. A. Renninger, S. Hidi, \& A. Krapp (Eds.), The role of interest in learning and development (pp. 183-212). Hillsdale: Erlbaum.

Schiefele, U., Schaffner, E., Möller, J., \& Wigfield, A. (2012). Dimensions of reading motivation and their relation to reading behavior and competence. Reading Research Quarterly, 47(4), 427-463. https://doi.org/10.1002/rrq.030.

Schultz, G. F. (1993). Socioeconomic disadvantage and achievement motivation: Important mediators of academic performance in minority children in urban schools. The Urban Review, 25(3), 221-232.

Schunk, D. H., Pintrich, P. R., \& Meece, J. L. (2008). Motivation in education: Theory, research, and applications. Upper Saddle River: Pearson Education. 
Shapira, M. (2012). An exploration of differences in mathematics attainment among immigrant pupils in 18 OECD countries. European Educational Research Journal, 11, 68-95.

Sirin, S. R. (2005). Socioeconomic status and academic achievement: A meta-analytic review of research. Review of Educational Research, 75(3), 417-453. https://doi.org/10.3102/00346543075003417.

Skinner, E., Furrer, C., Marchland, G., \& Kindermann, T. (2008). Engagement and disaffection in the classroom: Part of a larger motivational dynamic? Journal of Educational Psychology, 100, 765-781.

Snow, C. E., \& Dickinson, D. K. (1990). Social sources of narrative skills at home and at school. First Language, 10, 87-103.

Taboada, A., Tonks, S. M., Wigfield, A., \& Guthrie, J. T. (2009). Effects of motivational and cognitive variables on reading comprehension. Reading and Writing, 22, 85-106.

Tingley, D., Yamamoto, T., Hirose, K., Keele, L., Imai, K. (2014). Mediation: R package for causal mediation analysis. Journal of Statistical Software, 59(5), 1-38. http://www.jstatsoft.org/v59/i05/.

Tramonte, L., \& Willms, J. D. (2010). Cultural capital and its effects on education outcomes. Economics of Education Review, 29(2), 200-213.

Unrau, N., \& Schlackman, J. (2006). Motivation and its relationship with reading achievement in an urban middle school. The Journal of Educational Research, 100(2), 81-101.

Van de Vijver, F. J. R. (2015). Methodological aspects of cross-cultural research. In M. Gelfand, Y. Hong, \& C. Y. Chiu (Eds.), Handbook of advances in culture and psychology (Vol. 5, pp. 101-106). New York: Oxford University Press.

Van Steensel, R. (2006). Relations between socio-cultural factors, the home literacy environment and children's literacy development in the first years of primary education. Journal of Research in Reading, 29, 367-382.

von Maurice, J., Dörfler, T., \& Artelt, C. (2014). The relation between interests and grades: Path analyses in primary school age. International Journal of Educational Research, 64, 1-11.

Weigel, D. J., Martin, S. S., \& Bennett, K. K. (2006). Contributions of the home literacy environment to preschool-aged children's emerging literacy and language skills. Early Child Development and Care, 176, 357-378.

Wigfield, A., \& Eccles, J. S. (2000). Expectancy-value theory of achievement motivation. Contemporary Educational Psychology, 25(1), 68-81.

Wigfield, A., Eccles, J. S., Fredricks, J., Simpkins, S., Roeser, R., \& Schiefele, U. (2015). Development of achievement motivation and engagement. In R. M. Lerner, C. Garcia, \& M. Lamb (Eds.), Handbook of child psychology and developmental science: Vol. 3. Social and emotional development (7th ed., Vol. 3, pp. 657-700). Hoboken: Wiley.

Wigfield, A., Tonks, S., \& Klauda, S. L. (2009). Expectancy-value theory. In K. R. Wentzel \& A. Wigfield (Eds.), Handbook of motivation at school (pp. 55-75). New York: Routledge.

Willms, J. D. (2003). Ten hypotheses about socioeconomic gradients and community differences in children's developmental outcomes. Quebec, Canada: Applied Research Branch of Strategic Policy. http://publications.gc.ca/collections/ Collection/RH63-1-560-01-03E.pdf.

Willms, J. D. (2006). Learning divides: Ten policy questions about the performance and equity of schools and schooling systems. http://unesdoc.unesco.org/images/0014/001470/147066e.pdf.

Wong, M. M. (2008). Perceptions of parental involvement and autonomy support: Their relations with self-regulation, academic performance, substance use and resilience among adolescents. North American Journal of Psychology, 10, 497-518.

Yang Hansen, K., Rosén, M., \& Gustafsson, J.E. (2011). Changes in the multi-level effects of socio-economic status on reading achievement in Sweden in 1991 and 2001. Scandinavian Journal of Educational Research, 55(2), 197-211. 